\title{
Narin Çelik Kirişlere Stabilite Desteği Sağlayan Kayma Diyaframlarının Rijitlik Gereklilikleri
}

\author{
Oğuz Özgür EĞílLMEZ ${ }^{1}$ \\ Andaç AKBABA ${ }^{2}$ \\ Mustafa VARDAROĞLU ${ }^{3}$
}

$\ddot{O} \mathbf{z}$

Çelik I-kirişlerin burkulma kapasitesi, noktasal veya sürekli destek elemanları kullanılarak artırılmaktadır. Yapım aşamasında taze betonu taşımak için kiriş uzunluğunca kullanılan trapez sac kalıplar, bir kayma diyaframı gibi davranırlar ve çelik kirişlere sürekli destek sağlarlarlar. Bir destek elemanının görevini yerine getirebilmesi için yeterli rijitliğe ve dayanıma sahip olması gerekmektedir. Narin gövdeli çelik kirişleri destekleyen kayma diyaframlarının rijitlik gerekliliklerini araştırmak için sayısal bir çalışma yapılmıştır. Çift ve tek simetri eksenli kesitler incelenmiştir. Kiriş orta açıklığında noktasal destek elemanı bulunduran kirişler de analiz edilmiştir. Narin gövdeli çelik I-kirişleri destekleyen kayma diyaframları için minimum rijitlilik gereklilikleri önerilmiştir.

Anahtar Kelimeler: Kayma diyaframı, çelik I-kiriş, sürekli stabilite bağlantısı, minimum rijitlik gerekliliği.

\begin{abstract}
Stiffness Requirements for Shear Diaphragms Used for Stability Bracing of Slender Steel Beams

The buckling resistance of steel I-beams can be increased by providing lateral bracing along the length of the beams by either cross-frames or diaphragms. Metal sheeting that is often used in steel buildings and bridge constructions to support the fresh concrete, acts like a shear diaphragm and provides continuous bracing to steel beams. An adequate bracing system must possess sufficient stiffness and strength. A computational study was conducted to investigate stiffness requirements of shear diaphragms used to brace slender steel Ibeams. Both double and single symmetrical axis sections were studied. Beams that are braced by cross-frames in addition to diaphragms have also been investigated. Stiffness requirements have been proposed for shear diaphragms used to brace slender steel I-beams.
\end{abstract}

Keywords: Shear diaphragm, steel beam, continuous bracing, stiffness requirements.

\footnotetext{
Not: Bu yazı

- Yayın Kurulu'na günü ulaşmıştır.

- 31 Aralık 2017 gününe kadar tartışmaya açıktır.

- DOI: $10.18400 /$ tekderg. 331522
}

1 İzmir Ekonomi Üniversitesi, İnşaat Mühendisliği Bölümü, İzmir - ozgur.egilmez@ieu.edu.tr 2 İzmir Yüksek Teknoloji Enstitüsü, İnşaat Müh. Bölümü, İzmir - andacakbaba@iyte.edu.tr

3 İzmir Yüksek Teknoloji Enstitüsü, İnşaat Müh. Bölümü, İzmir - mustafavardaroglu@iyte.edu.tr 
Narin Çelik Kirişlere Stabilite Desteği Sağlayan Kayma Diyaframlarının...

\section{GIIRIŞ}

Çelik I-kirişlerin tasarımında, yapım aşamasında belirleyici olabilecek sınır durumlarından bir tanesi yanal burulmalı burkulmadır. Bu kritik yapım aşamasında, kirişlerin burkulma kapasitesinin artırılması için noktasal veya sürekli destek elemanları ile kirişlerin desteklenmeyen uzunluğunun kısaltılması gereklidir. Çelik bina ve köprü inşaatlarında taze betonu taşıması için sıklıkla kullanılan trapez sac plakalar, kiriş uzunluğu boyunca sürekli bir kayma diyarfamı gibi davranırlar ve kompozit etkileşimin başlamadığı çelik kirişlerin üst başlıklarına sürekli bir yanal destek sağlarlar. Çelik bina endüstrisinde, kayma diyaframlarının kiriş üst başlıklarını yanal olarak destekledikleri kabul edilir. Çelik köprü endüstrinde ise kayma diyaframlarının kirişleri yanal olarak destekledikleri kabul edilmez [3]. Bunun başlıca sebebi trapez sac plakalar ile kiriş üst başlığı bağlantısının eksantrik olmasıdır. Köprü endüstrisinde trapez sac plakalar genellikle, eksantrik olarak üst başlığa kaynatılan köşebentlere vidalanırlar. Bu eksantriklik ise diyafram destek siteminin rijitliğini azaltır. Ancak son yıllarda yapılan çalışmalarda, basit bir bağlantı modifikasyonu sayesinde eksantrik bağlantının sebep olduğu rijitlik kaybının önüne geçilebildiği görülmüştür $[7,8$, 9]. Bu araştırmaların sonuçları Houston'da (Teksas, ABD) üç yüz ellişer adet 50 metre serbest açıklıklı ve basit mesnetli çelik kirişten oluşan 2 adet köprü inşaatında uygulanmıştır [10]. Bu uygulama sayesinde 680 adet noktasal destek elemanından tasarruf sağlanmıştır.

Bir destek elemanının deformasyonları ve kuvvetleri kontrol edebilmesi için yeterli rijitliğe ve dayanıma sahip olması gerekmektedir $[18,20]$. Kayma diyaframları, diyafram düzlemi içinde yüksek bir rijitliğe ve dayanıma sahiptirler ve bağlandıkları kiriş üst başlığına sürekli bir yanal destek sağlamaktadırlar. Kayma diyaframlarının destek elemanları olarak tasarlanabilmeleri için rijitlik ve dayanım gerekliliklerinin belirlenmesi gerekmektedir. $\mathrm{Bu}$ konudaki çalışmalardan en kapsamlısı Helwig ve Yura $[13,14]$ tarafindan yapılmıştır. Helwig ve Yura $[13,14]$ yaptıkları bu çalışmada kayma diyaframları tarafından desteklenen ve gövde narinlik oranı $60^{\prime}$ tan düşük olan kompakt gövdeli kirişleri irdelemişlerdir. Çalışmada, deformasyon ve destek kuvvetlerinin kontrol edilebilmesi için gerekli olan diyafram rijitliğinin, ideal diyafram rijitliğinin 4 katı olduğu belirtilmiştir. Bunun yanında, bu çalışmada kayma diyaframlarının kiriş üst başlıklarına bağlandıkları kısa kenar vida birleşimlerinde oluşacak olan destek kuvvetlerinin tahmin edilmesini sağlayan denklemler geliştirilmiştir. Bir kayma diyafram plakasında oluşan vida destek kuvvetleri Şekil 1'de gösterilmiştir. Şekilde görüldüğü gibi kayma diyaframlarında iki çeşit vida birleşimi bulunmaktadır: 1) kayma diyaframlarını kiriş üst başlığına bağlayan kısa kenar vida birleşimleri; 2) kayma diyaframlarını birbirlerine bağlayan yan vida birleşimleri. Helwig ve Yura $[13,14]$, yaptıkları bu çalışmada yan vida birleşimlerinde oluşan destek kuvvetlerinin diyafram rijitliğine ve dayanımına etkilerini incelememişlerdir.

Gövde narinlik oranı 60'tan yüksek olan ve kayma diyaframı ile desteklenen narin kirişlerle ilgili çalışmalar ise daha azdır. Helwig ve Frank [12] kayma diyaframı ile desteklenen narin kirişlerin burkulma momentinin hesaplanması için denklemler önermişlerdir. Ancak yazarların bildiği kadarıyla, narin kirişleri destekleyen kayma diyaframlarının sahip olması gereken rijitlik ve dayanım gereklilikleri ile ilgili bir çalışma literatürde bulunmamaktadır. $\mathrm{Bu}$ çalışmada, basit mesnetli narin I-kirişleri destekleyen kayma diyaframların rijitlik gereksinimleri irdelenmektedir. Çalışmada hem çift simetri eksenli hem de tek simetri eksenli I-enkesitlere yer verilmiş̧ir. Kiriş uzunluk/derinlik oranı $(L / d) 10$ ve 15 olan kirişler 
incelenmiştir. $L / d$ oranı daha yüksek olan kirişler, montaj esnasında genellikle noktasal çapraz veya rijit birleşimli I- ve U-enkesitli destek elemanlarına ihtiyaç duyarlar. Noktasal destek elemanlarının diyafram rijitlik gerekliliğine etkisini araştırmak için $L / d$ oranı 20 ve 30 olan kirişler için de çözümlemeler yapılmıştır. Bir trapez sac kayma diyaframının rijitliği, sac plakanın ve plakaları kiriş üst başlığına ve birbirlerine bağlayan vida birleşimlerinin rijitliklerine bağlıdır $[15,5]$. Bu çalışmada kullanılan sonlu elemanlar modelinde hem diyaframı kiriş üst başlığına bağlayan kısa kenar vida birleşimleri hem de diyaframları birbirlerine bağlayan yan kenar vida birleşimleri modellenmiştir. Böylece her iki vida birleşiminin diyafram destek sisteminin rijitlik gereksinimine etkisi araştırılmıştır. Destek elemanlarında oluşan destek kuvvetleri, destek elemanının rijitliğiyle doğrudan orantılıdır [21]. Bu sebeple, destek elemanlarının dayanım gereklilikleri genellikle belirli bir destek elemanı rijitliğine göre belirlenir. Bu çalışmada elde edilen veriler, daha sonraki bir çalışmada narin kirişleri destekleyen kayma diyaframlarının dayanım gerekliliklerinin hesaplanmasında kullanılacaktır.

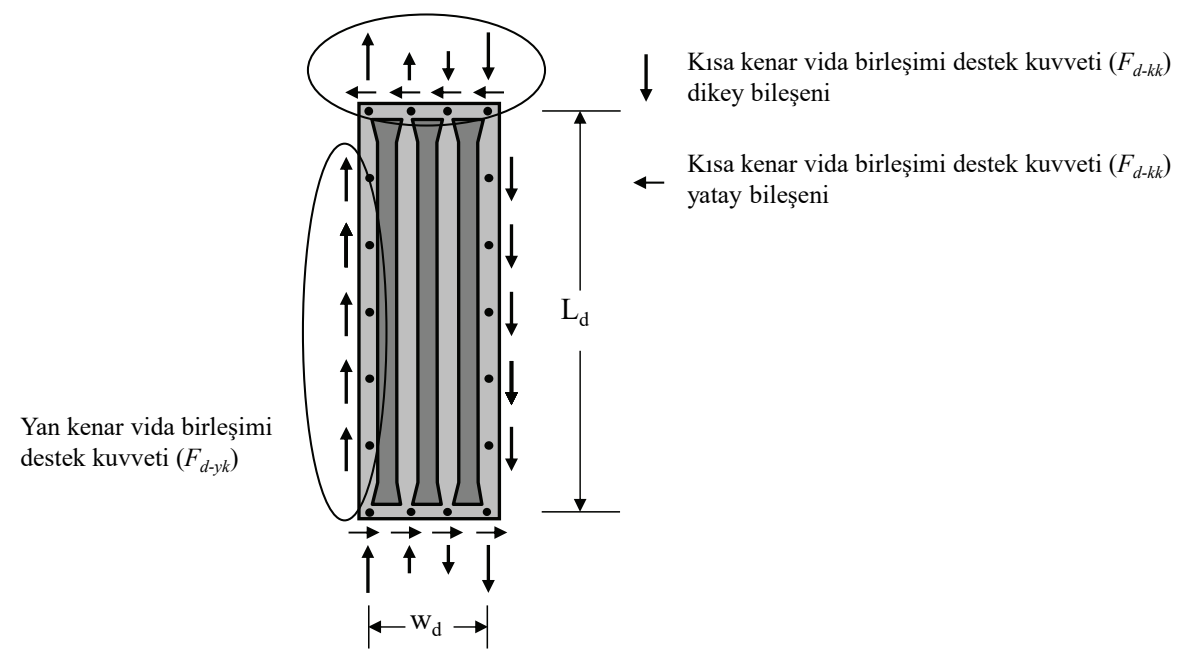

Şekil 1. Kayma diyaframı palkasında oluşan vida destek kuvvetleri

$\mathrm{Bu}$ makalede ilk olarak önceki çalışmalar hakkında bilgi verilecektir. Ardından, sonlu elemanlar modeli tanıtılacak ve çalışmanın kapsamı hakkında bilgi verilecektir. Çözümleme sonuçları ile diyafram rijitlik gereklilikleri açıklandıktan sonra, makale kısa bir sonuç bölümüyle son bulacaktır.

\section{2. ÖNCEKI ÇALIŞMALAR}

Kayma diyaframı ile desteklenmiş kirişlerin burkulma davranışı önceki yıllarda birçok araştırmacı tarafından incelenmiş̧ir. 1970'li yılların ortalarında Errera ve Apparao [11] düzgün yayılı moment etkisi altında olan ve kayma diyaframı ile desteklenmiş kirişlerin burkulma momenti için aşağıdaki enerji tabanlı denklemi önermiştir: 
Narin Çelik Kirişlere Stabilite Desteği Sağlayan Kayma Diyaframlarının...

$M_{c r}=\sqrt{\left(\frac{\pi^{2} E I_{y}}{L^{2}}+Q\right)\left(\frac{\pi^{2} E C_{w}}{L^{2}}+G J+Q e^{2}\right)}+Q e$

Bu denklemde $M_{c r}=$ kayma diyaframı ile desteklenmiş kirişin burkulma momenti $(\mathrm{kN} / \mathrm{m}) ; E$ $=$ elastisite modülü $(M P a) ; G=$ kayma modülü $(\mathrm{kN} / \mathrm{m} / \mathrm{rad}) ; I_{y}=$ kirişin zayıf ekseni etrafinda atalet momenti $\left(\mathrm{mm}^{4}\right) ; J=$ burulma sabiti $\left(\mathrm{mm}^{4}\right) ; C_{w}=$ çarpılma sabiti $\left(\mathrm{mm}^{6}\right) ; L=$ kirişin desteklenmemiş uzunluğu $(\mathrm{mm}) ; Q=$ kayma diyaframının kayma sıkılığı $(\mathrm{kN} / \mathrm{rad})$; ve $e=$ kirişin ağırlık merkezi ile kayma diyaframının düzlemi arasındaki mesafedir $(\mathrm{mm})$. Kuvvet bölü birim radyan $(k N / r a d)$ birimine sahip olan kayma diyaframı sıkılığı, $Q$, diyafram destek sisteminin etkili kayma rijitliği, $\beta^{\prime}$, ile tek bir kirişi destekleyen diyafram genişliğinin, $s_{d}$, çarpılması ile hesaplanır. Kayma diyaframı sıkılığı, $Q$, kirişin 1 radyan kayma şekildeğiştirmesine karşı kayma diyaframının gösterdiği direnci ifade etmektedir. Luttrell [15], diyaframlar için kayma gerilmesi-gerinimi ilişkisinin diyafram kalınlığına doğrudan bağlı olmadığını göstermiştir. $\mathrm{Bu}$ sebeple, diyafram sıkılığının $(Q)$ hesaplamasında, geleneksel kayma rijitliği, $\beta$, yerine, etkili kayma rijitliği, $\beta^{\prime}$, kullanılmaktadır. Kayma diyaframlarının etkili kayma rijitliği, $\beta^{\prime}$, deneysel olarak hesaplanabildiği gibi, literatürde bulunan denklemlerin $[15,16]$ kullanılmasıyla da hesaplanabilmektedir.

Nethercot ve Trahair [17] ile Errera ve Apparao [11] düzgün yayılı moment etkisi altında olan ve kayma diyaframı ile desteklenmiş kirişlerin burkulma momenti için daha basit bir denklem önermişlerdir:

$$
M_{c r}=M_{g}+2 Q e
$$

Bu denklemde $M_{g}=$ kirişin desteklenmemiş uzunluğundaki burkulma momentini $(k N-m)$ ifade eder. Diğer parametreler daha önce açıklanmıştır. 1990'lı yılların sonunda Helwig ve Frank [12] yukarıda bahsedilen çalışmaları geliştirerek, değişik eğilme momenti yayılışlarına sahip ve kayma diyaframı ile desteklenmiş kirişlerin burkulma momenti için bir denklem önermişlerdir:

$$
M_{c r}=C_{b}^{*} M_{g}+m Q d
$$

Bu denklemde $M_{c r}=$ kayma diyaframı ile desteklenmiş kirişin burkulma momenti $(k N-m)$; $C_{b}{ }^{*}=$ yük yüksekliğini de hesaba katan moment düzeltme katsayısı; $M_{g}=$ kirişin desteklenmeyen uzunluğu kullanılarak elde edilen burkulma momenti $(k N-m) ; m=$ yük konumu sabiti; $Q=$ kayma diyaframının kayma sıkılığ $(\mathrm{kN} / \mathrm{m} / \mathrm{rad})$; ve $d=$ kiriş derinliğidir (mm). Bu çalışmada Helwig ve Frank [12] gövde narinlik oranı 96 ve 160 olan kirişleri incelmişlerdir. Helwig ve Frank [12] $\mathrm{m}$ sabiti için 0.5 (yükün ağırlık merkezinde uygulandığı durum) ve 0.375 (yükün üst başlıkta uygulandığı durum) değerlerini önermişlerdir. 2000'li yılların sonunda Helwig ve Yura [13], Helwig ve Frank'in [12] çalışmasını $h / t_{w}$ oranı 60 olan kirşlere uyarlamışlar ve bu tür kirişler için $m$ değerini yükün 
ağırlık merkezinde uygulandığı durum için 0.85 , yükün üst başlıkta uygulandığı durum için 0.5 olarak önermişlerdir.

Denklem (2) ve (3) geometrik ön kusuru olmayan düz kirișler için tanımlanmıştır. Bu sebeple, bu denklemleri kullanarak hesap edilecek diyafram rijitliği, ideal diyafram rijitliğini ifade edecektir. İdeal diyafram rijitliği Denklem (3) kullanılarak aşağıdaki gibi hesaplanabilir:

$$
\begin{aligned}
& \beta_{i}^{\prime}=\frac{Q_{i}}{s_{d}}=\frac{\left(M_{u}-C_{b}^{*} M_{g}\right)}{m d s_{d}} \\
& s_{d}=\frac{(n-1) s_{g}}{n}
\end{aligned}
$$

Bu denklemde $\beta{ }_{i}^{\prime}=$ etkili ideal kayma diyaframı rijitliğini $(\mathrm{kN} / \mathrm{m} / \mathrm{rad}) ; Q_{i}=$ ideal diyafram sıkılığını $(\mathrm{kN} / \mathrm{rad}) ; M_{u}=$ kiriş uzunluğundaki tasarım momentini $(\mathrm{kN}-\mathrm{m}) ; n=$ toplam kiriş adetini; $s_{d}=$ bir kirişi destekleyen diyafram uzunluğu $(\mathrm{mm})$ ve $s_{g}=$ kirişler arası mesafeyi $(\mathrm{mm})$ ifade eder. Diğer parametreler daha önce açıklanmıştır. Yapısal bir elemanın tasarlanan kapasiteye ulaşmasını sağlayacak destek elemanı rijitliği genel olarak "ideal rijitlik" olarak tanımlanır. Helwig ve Yura [14] $h / t_{w}$ oranı 60 olan kirişleri destekleyen kayma diyaframlarının rijitlik gerekliliğini hesap etmek için çözümlemeler yapmışlardır. Çalışmalarında, diyaframın "ideal rjitliğini”, kiriş dış lifinde $345 \mathrm{MPa}$ eğilme gerilmesi oluşmasını sağlayacak diyafram rijitliği olarak kabul etmişlerdir. Helwig ve Yura [14] deformasyon ve destek kuvvetlerinin kontrol edilebilmesi için ideal diyafram rijitliğinin 4 katının sağlanmasını önermişlerdir. İdeal rijitliğin 4 katını kullanmak şu denkelemi ortaya çıkarmaktadır:

$$
\beta_{b r}^{\prime}=4 \beta_{i}^{\prime}=4 \frac{Q_{i}}{s_{d}}=4 \frac{\left(M_{u}-C_{b}^{*} M_{g}\right)}{m d s_{d}}
$$

Bu denklemde $G_{b r}^{\prime}=$ deformasyon ve destek kuvvetlerinin kontrol edilebilmesi için gerekli olan diyafram rijitliği $(\mathrm{kN} / \mathrm{m} / \mathrm{rad}) ; M_{u}=\operatorname{tasarım}$ momenti $(\mathrm{kN}-\mathrm{m}) ; \beta_{i}^{\prime}=M_{u}$ 'ya ulaşmak için sağlanması gereken ideal diyafram rijitliği $(\mathrm{kN} / \mathrm{m} / \mathrm{rad}$ ) (Denklem (4) kullanılarak elde edilir); $C_{b}{ }^{*}, M_{g}, m, d$, ve $s_{d}$ daha önce tanımlanmıştır.

\section{SONLU ELEMANLAR MODELI}

$\mathrm{Bu}$ çalışmada sayısal çözümlemeler yapmak için ANSYS [1] sonlu elemanlar programı kullanılmıştır. Sonlu elemanlar modeli, Şekil (2)'de gösterildiği gibi üst başlıkları kayma diyaframı ile birbirine bağlanmış ikiz kirişlerden oluşmaktadır. Modelde sadece doğrusal elastik malzeme özelliklerine sahip elemanlar kullanılmıştır. Bu çalışmada kayma 
Narin Çelik Kirişlere Stabilite Desteği Sağlayan Kayma Diyaframlarının...

diyaframı ile desteklenmiş kirişlerin yanal stabilitesi, beton dökümü aşamasında, yani gerilmelerin düşük olduğu aşamada incelendiği için doğrusal olmayan malzeme özelliği içeren elemanlar modelde kullanılmamıştır. Çelik kirişler ve gövdelerde kullanılan berkitme levhaları 8-düğüm noktalı plaka elemanlar kullanılarak modellenmiştir. Başlıklarda iki, gövdelerde ise dört eleman kullanılmıştır. Elemanların en/boy oranı 1.2 ile 2.9 arasında değişmektedir. Kirişler basit mesnetlidir ve mesnetler düzlem dışı harekete izin vermeyecek şekilde yaratılmıştır. Kirişlere Şekil (2)'de gösterilen bir ön kusur tanımlanmıştır. Bunun sebebi, geometrik ön kusurların, destek kuvvetlerinin sayısal değerinde önemli bir rol oynamalarıdır. Wang ve Helwig [19], noktasal (örnek: çaprazlı stabilite bağlantısı) ve sürekli (örnek: diyafram) destek elemanları ile desteklenmiş kirişlerde oluşan destek kuvvetleri sayısal değerinin, kirişin geometrik ön koşulunun Şekil (2)'deki gibi olması durumunda en yüksek seviyeye ulaştığını göstermişlerdir. Şekil (2)'de gösterilen $L_{b}$, diyaframsız kirişin mesnetler arası uzunluğunu ifade etmektedir.

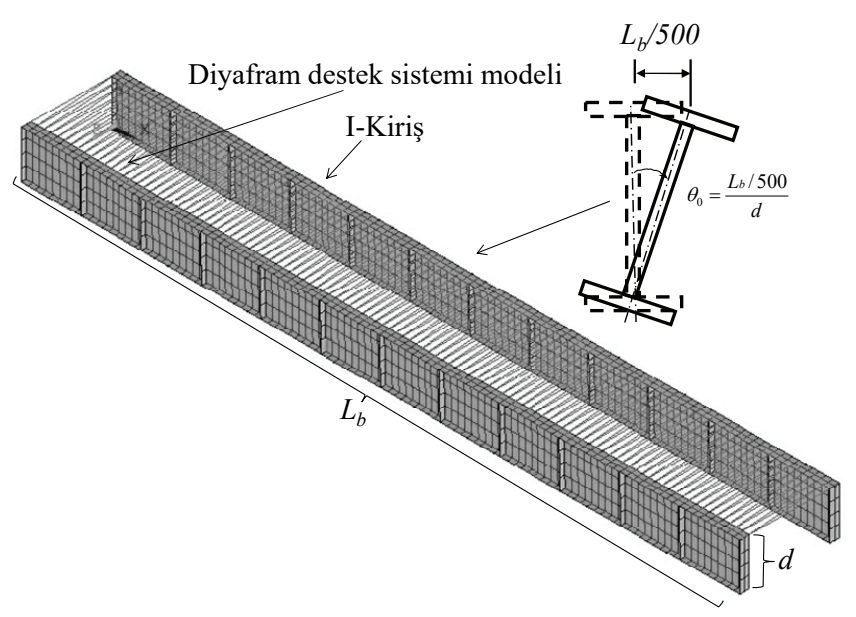

Şekil 2. Sonlu elemanlar modeli ve kiriş ön kusuru

Kayma diyaframı modeli, Davies ve Bryan'ın (1982) düzlem içi yüklerin diyafram rijitliğine ve dayanımına etkilerini araştıran bir çalışmalarından alınmıştır. Bu çalışmada Davies ve Bryan (1982) kayma diyaframını, Şekil (3)'de gösterildiği gibi birbirine bağlanmış küçük makas sistemlerinden oluşturmuşlardır. Şekil (3)'de gösterilen her bir küçük makas dört adet dikey ve üç adet çapraz makas elemanından oluşmuştur. Dikey makas elemanlarının rijitliği çok yüksek tanımlanmış ve böylece bu dikey elemanların sistem rijitliğini etkilemeleri önlenmiştir. Diyafram sisteminin rijitliği ise çapraz makas elemanların rijitliği ile diyaframları üst başlığa ve birbirlerine bağlayan vida birleşimlerinin rijitlikleriyle belirlenmiştir. Diyaframın her bir dikey makas elemanı kiriş üst başlığına, diyafram-kiriş üst başlık vida bağlantısını temsil eden ve Şekil (4)'de gösterilen boyutsuz yay elemanları aracılı̆̆ ile bağlanmıştır. Bu yay elemanları, düzlem içindeki her iki yönde de aynı rijitliğe sahiptirler. Diyafram-kiriş üst başlığı birleşimi, genellikle $6 \mathrm{~mm}$ çapında vidalar ile birleştirilir. Yay elemanlarının rijitlik değeri, benzer bağlantıların rijitliklerinin 
tanımlandığı bir çalışmadan alınmıştır [16]. Bu yay elemanları Şekil (3)'de boyutlu gibi görülmektedir. Ancak bu gösterim sadece okuyucuya görsel kolaylık sağlamak için yapılmıştır. Bu yaylar modelde boyutsuzdur. Kirişlerin uçlarında (mesnet bölgeleri), diyafram plakaları genellikle bir kirişi diğer kirişe bağlayan rijit birleşimli I- veya Uenkesitli destek elemanlarına bağlanırlar. Bu vida bağlantıları da yine boyutsuz yay elemanları kullanılarak modele yansıtılmıştır.

Diyafram plakaları, montaj esnasında yanlardan birbirlerinin üzerine bindirilirler ve yine 6 $\mathrm{mm}$ çapında metal birleştirme vidaları ile birbirlerine vidalanırlar. $\mathrm{Bu}$ yan kenar birleşimlerinin rijitliği de Şekil (3)'de görülen yan birleşim makas elemanı kullanılarak modellenmiştir. Bu yan birleşim makas elemanları Şekil (3)'de çapraz gözükmektedir. Ancak gerçekte, bu makas elemanları iki kiriş arasında dikey olarak yerleştirilmişlerdir. Makas elemanın bir ucu bir diyaframa bağlanmışken, diğer ucu diğer diyaframa bağlanmıştır. Bu yan birleşim makas elemanlarının rijitliği, birleşimde kullanılan toplam vida birleşimlerinin rijitliklerinin toplamına eşittir. Bir adet yan vida birleşimi rijitliği, yine benzer vida birleşimlerinin rijitliğini veren çalışmalardan alınmıştır [16].

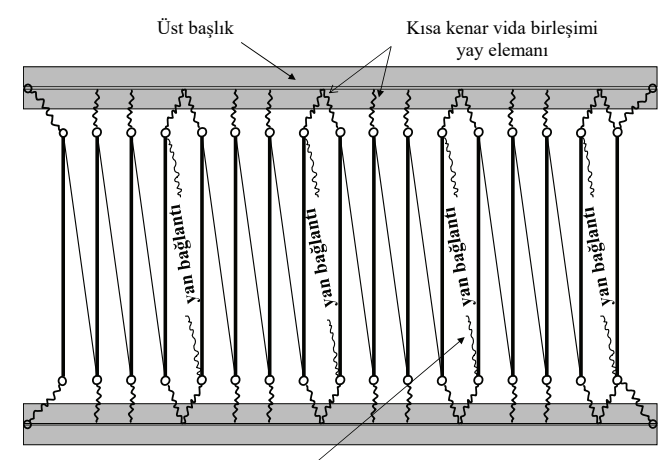

Yan bağlantı vida birleşimi makas elemanı

Şekil 3. Diyafram destek sisteminin sonlu elemanlar modeli

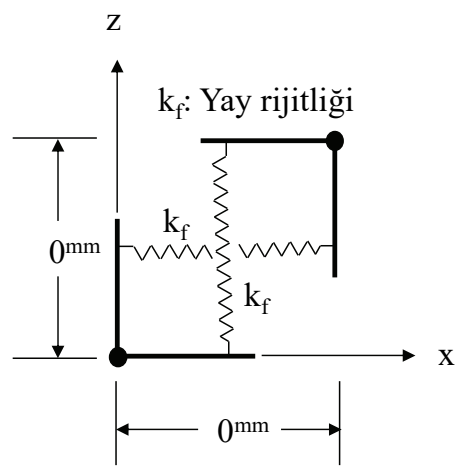

Şekil 4. Vida bağlantıları sonlu elemanlar modeli 
Narin Çelik Kirişlere Stabilite Desteği Sağlayan Kayma Diyaframlarının...

Bugün piyasada, değişik uzunluk ve genişlikte birçok trapez sac plaka (diyafram plakası) mevcuttur. Bu çalışmada kullanılan diyafram modeli, herhangi bir tip diyafram plakasını temsil etmemektedir. Ancak modellenen diyafram plakaları, bina ve köprü inşaatlarında sıklıkla kullanılan diyafram tiplerine benzer şekilde, kiriş üst başlığına 4 adet vida ile bağlanmışlardır. Diyafram yanlarında ise beşer adet yan vida birleşimi olduğu varsayılmıştır. Kayma diyaframıyla desteklenen kirişlerin burkulma kapasitesi, diyafram destek sisteminin toplam rijitliğine bağlı olarak değişmektedir. Denklem (3)'de kullanılan $Q$ (diyafram sıkılığı) değeri, daha önce belirtildiği gibi diyafram destek sisteminin etkili kayma rijitliği $(\beta)$ ile tek bir kirişi destekleyen diyafram genişliğinin $\left(s_{d}\right)$ çarpılması ile hesaplanır. Bir diyafram destek sistemi, diyafram plakasının kendisi, diyaframın kiriş üst başlıklarına bağlandığı kısa kenar vida birleşimi ve diyaframların yanlardan birbirlerine bağlandıkları yan kenar vida birleşimlerinden oluşur. Bina ve köprü tasarımcıları, bu çalışma sonuçlarını kullanarak elde edecekleri gerekli diyafram destek sistemi rijitliğini $\left(\beta^{\prime}{ }_{b r}\right)$ sağlayacak diyafram destek sistemini (diyafram plakası tipi, diyafram-kiriş üst başlık bağlantı vida sayısı ve yan vida birleşimi sayısı), literatürdeki deney sonuçlarını [15] veya önerilen denklemleri [16,5] kullanarak belirleyebileceklerdir.

Yukarıda açıklanan sonlu elemanlar modelinin doğrulaması Eğilmez ve Alkan'ın [6] çalışmasında ayrıntılı olarak verilmiştir. Modelin kendisi ve doğrulaması ile ilgili daha ayrıntılı bilgiler Eğilmez ve Alkan'ın [6] çalışmasından elde edilebilir.

\section{4. ÇALIŞMAYA GENEL BAKIŞ}

$\mathrm{Bu}$ çalışmada dört adet çift simetri eksenli ve altı adet tek simetri eksenli kesit incelenmiş̧tir. İncelenen bu kesitler Şekil 5'de gösterilmiştir. Kesitlerin gövde narinlik oranları $\left(h / t_{w}\right) 100$ ve 160 'dır. Çift simetri eksenli kesitler, $h / t_{w}$ oranlarına (100 veya 160$)$ ve derinliklerine (\#1: $d=1464 \mathrm{~mm}, \# 2: d=1830 \mathrm{~mm}$ ) göre isimlendirilmişlerdir: ÇS-100 \#1 ve \#2 ile ÇS-160 \#1 ve \#2. Çift simetri eksenli kirişlerin başlık narinlik $\left(b / t_{f}\right)$ oranı 6 , başlık genişliği 300 milimetredir. Tek simetrili kesitler ise $h / t_{w}(100$ veya 160$)$ ve mono-simetri $\left(I_{y d} I_{y}\right.$ [Basınç başlığının y-eksenine göre atalet momentinin kesitin y-eksenine göre atalet momentine oranı] $=0.19,0.29$ ve 0.39 ) oranlarına göre isimlendirilmişlerdir: TS-100 $\# 19$, $\# 29$ ve \#39 ve TS-160 \#19, \#29 ve \#39. AASHTO LRFD [3] tek simetrili kirişlerde $I_{y c} / I_{y}$ oranının 0.1 ve 0.9 arasında olmasını şart koşmaktadır. Tek simetrili kirişlerde tek bir derinlik incelenmiştir: $d=1464 \mathrm{~mm}$. Daha yüksek derinliklere sahip tek simetrili kirişler, kendi ağırlıklarını taşımakta bile zorlanmakta ve montaj esnasında dahi destek elemanına ihtiyaç duymaktadır. Alt başlık genişliği 300 milimetredir. Üst başlık genişlikleri, istenilen $I_{y c} / I_{y}$ oranına göre ayarlanmıştır. Her iki başlığın başlık narinlik oranları 6'dır. Kiriş gövdelerinde, gövde kayma burkulmasını önlemek için kiriş uzunluğu boyunca $a / h$ oranı 1 olacak şekilde berkitme levhaları kullanılmıştır.

Kiriş uzunluğunun derinliğine oranı (L/d) 10 ve 15 olan basit mesnetli kirişler incelenmiştir. $\mathrm{Bu}$ oranın daha yüksek olduğu basit mesnetli kirişler, kendi ağılıklarını taşımak için genellikle noktasal çapraz veya rijit birleşimli I- ve U-enkesitli destek elemanlarına ihtiyaç duyarlar. Kiriş orta noktasına bağlanmış noktasal çapraz destek elemanlarının diyafram rijitlik gerekliliğine etkisini araştırmak için $L / d$ oranı 20 ve 30 olan kirişler için de analizler yapılmıştır. Analizlerde tek tip yükleme dikkate alınmıştır: üst başlı̆ga etki eden düzgün yayılı yükleme. Helwig ve Yura [11], üst başlığa etki eden 
yüklemelerin, kiriş ağırlık merkezinden etki eden yüklere nazaran daha kritik olduğunu göstermişlerdir.

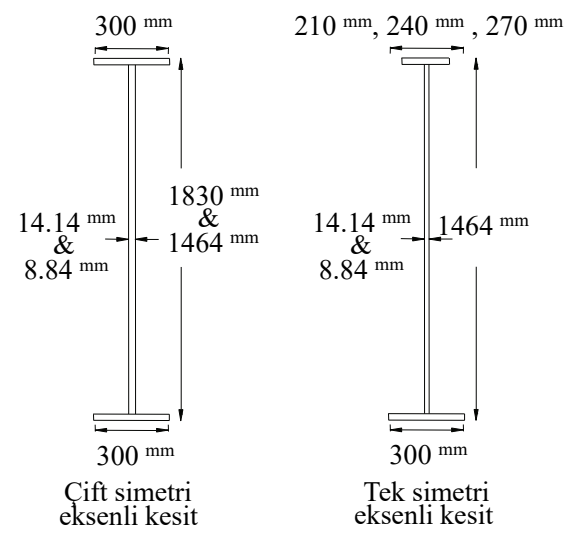

Şekil 5. Çalışmada kullanılan kesitleri

Literatürde, destek elemanı rijitlik gerekliliği genellikle destek elemanı ideal rijitliğinin katları olarak tanımlanmıştır [21, 12]. Daha önce belirtildiği gibi "destek elemanı ideal rijitliği”, desteklenen elemanın hedeflenen dayanıma ulaşması için sağlanması gereken rijitliği tarif eder. Ancak, ideal rijitliğe sahip destek elemanı tarafından desteklenen yapı elemanında yüksek deformasyonlar ve destek kuvvetleri oluşur. Bu yüksek deformasyon ve destek kuvvetlerini azaltmak için, ideal rijitlikten daha yüksek rijitliğe sahip bir destek elemanının kullanılması gerekmektedir. Daha önceki çalışmalarda ve çelik yapı şartnamelerinde [21, 12, 2], deformasyon ve destek kuvvetlerini kabul edilebilir değerlere indirmek için gerekli destek elemanı rijitliğinin, desteklenen yapı elemanına ve destek tipine bağlı olmak üzere ideal rijitliğin iki veya dört katı olması önerilmiştir. Bu "kabul edilebilir değerler"'in ne olduğu göreceli bir konu olsa da, hedeflenen dayanımda yapı elemanında oluşacak deformasyonu ön kusurun iki ile dört katı arasında sınırlamaya yetecek destek elemanı rijitliğinin, destek kuvvetlerini de yeteri derecede azaltacağını belirten çalışmalar mevcuttur [21, 12].

$\mathrm{Bu}$ çalışmada, kirişlerin yapım aşamasında tasarlanacağ tasarım momentinin kiriş dış lifinde $210 \mathrm{MPa}$ eğilme gerilmesi oluşturacak moment olduğu kabul edilmiștir. $210 \mathrm{MPa}$ eğilme gerilmesi değeri her ne kadar göreceli bir değer olsa da, akma gerilmesi $345 \mathrm{MPa}$ olan kirişler için, yapım aşamasında oluşabilecek gerilmelerin üst sınııında bir değerdir. $\mathrm{Bu}$ kabulün neticesinde, bu çalışmada kayma diyaframı "ideal rjitliği", kiriş dış lifinde 210 MPa eğilme gerilmesi oluşmasını sağlayacak diyafram rijitliğini ifade etmektedir. Çalışmada incelenen her bir kesit için öncelikle burkulma analizi yapılmıştır. Burkulma analizlerinin amacı, diyafram çapraz makas elemanlarının alanının, kirişin, kiriş dış lifinde $210 \mathrm{MPa}$ eğilme gerilmesi yaratacak düzgün yayılı yük altında burkulmasını sağlayacak şekilde kalibre edilmesini sağlamaktır. Bu alan belirlendikten sonra, Şekil 6'da gösterilen konsol çerçeve sonlu elemanlar modeli kullanılarak bu alanın ifade ettiği kayma diyaframı 
Narin Çelik Kirişlere Stabilite Desteği Sağlayan Kayma Diyaframlarının...

ideal sıkıllı̆ı belirlenmiştir. Şekilde gösterilen kayma diyaframı modeli, ikiz kiriş sonlu elemanlar modelinde kullanılan kayma diyaframı modelinin aynısıdır. Konsol çerçeve modelinde, diyafram çapraz makas elemanı kesit alanı olarak ikiz kiriş burkulma analiziyle belirlenen alan kullanılmıştır. Konsol çerçeveye birim bir yük uygulanmış ve çerçevede oluşan deformasyon değeri $(\Delta)$ elde edilmiştir. Ardından, Şekil 6'da belirtilen denklemler kullanılarak diyafram ideal sıkılığ 1 hesap edilmiştir. Kayma diyaframı ideal sıkılığ1 belirlendikten sonra bu sıkılığın iki, üç, dört ve beş katı sıkıllğa sahip diyaframlarla desteklenmiş ikiz kirişlerin ön kusurların hesaba katıldığı ve yükün kademeli olarak artırıldığı çözümlemeler yapılmışıtır. Çözümlemelerde tasarım yükü 12 adımda kirişlere uygulanmıştır. Her bir adım için kiriş ortasındaki dönme miktarı $(\theta)$ ile kısa kenar ve yan kenar vida birleşim destek kuvvetleri hesaplanmıştır. Sonuçlar bir sonraki bölümde açıklanmaktadır.

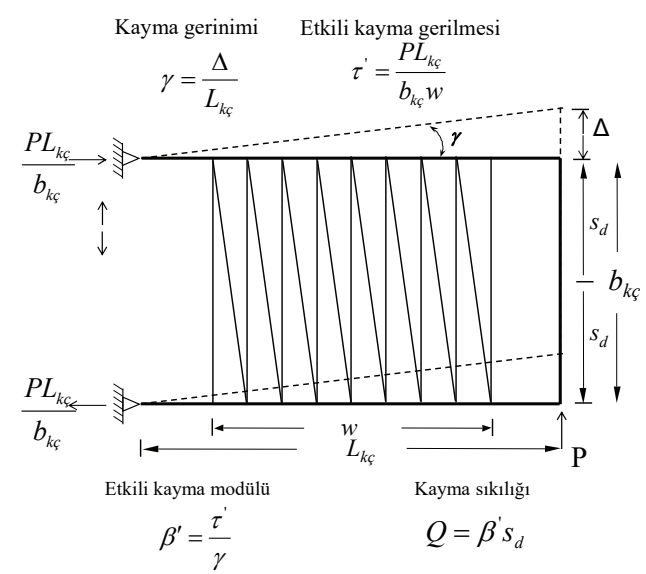

Şekil 6. Konsol çerçeve sonlu elemanlar modeli

\section{5. ÇÖZÜMLEME SONUÇLARI}

\section{1. Çift Simetri Eksenli Kirişler}

Sonlu elemanlar analiz sonuçları çift simetri eksenli kirişler için hem grafiksel hem de tablo olarak verilmiştir. Şekil 7'de, $L / d$ oranı 10 olan ÇS-100 \#1 kirişi için normalize edilmiş orta açıklı momenti ile normalize edilmiş orta açıklık dönmesinin ilişkisi gösterilmektedir. Dikey eksende belirtilen normalize edilmiş orta açıklı momenti $\left(M / M_{u}\right)$, her bir yük adımındaki orta açıklık momentinin $(M)$ tasarım momentine $\left(M_{u}\right)$ bölünmesiyle elde edilmiştir. Yatay eksende belirtilen normalize edilmiş orta açılklk dönmesi $\left(\theta_{t o p} / \theta_{0}\right)$ ise her bir yük adımındaki toplam orta açıklık dönme değerinin $\left(\theta_{\text {top }}=\theta+\theta_{0}\right)$ orta açılık ön kusur dönme değerine $\left(\theta_{0}=\left[\left(L_{b} / 500\right) / d\right]\right)$ bölünmesiyle elde edilmiştir. Şekilde görüldüğü gibi, kayma diyaframı ideal sıkılığının iki katı sıkılığa sahip diyaframla desteklenmiş kirişin, tasarım momenti seviyesindeki $\left(M / M_{u}=1.0\right)$ normalize edilmiş toplam dönme değeri 3.57'dir. Diyafram sıkılığı ideal sıkılığın 3, 4 ve 5 katına çıkarıldığında, tasarım momenti seviyesindeki normalize edilmiş toplam dönme değerleri 2.57, 2.24 ve 2.08'e düşmüştür. 


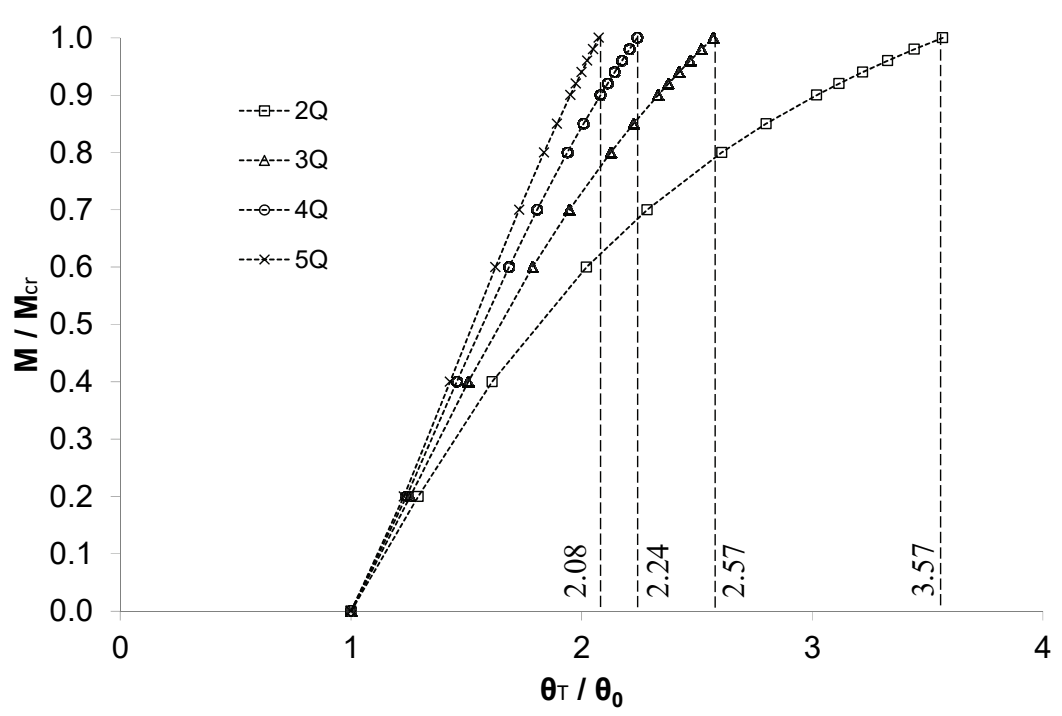

Şekil 7. L/d oranı 10 olan ÇS-100 \#1 kirişi için normalize edilmiş moment - normalize edilmiş dönme ĕgrisi

Çift simetri eksenli kirişlerin tümü için elde edilmiş sonlu elemanlar çözümleme sonuçları Tablo 1'de verilmiştir. Tablo 1, harflerle isimlendirilmiş 15 kolona bölünmüsşür. İlk kolon olan (a) kolonunda kesitin ismi yer almaktadır. Sonraki iki kolon (b) ve (c) kolonları) kesitin özelliklerini ve $L / d$ oranların içermektedir. Kayma diyaframı ideal sıkılığının 2, 3, 4 ve 5 katı sıkılığa sahip diyaframlarla desteklenmiş kirişlerde oluşan normalize edilmiş dönme değerleri (d), (e), (f) ve (g) kolonlarında verilmiştir. Aynı diyafram sıkılıklarında, diyaframın kısa kenar vida birleşimlerinde oluşan destek kuvvetleri $\left(F_{d-k k}\right)$ sırasıyla (h), (i), (j) ve (k) kolonlarında; diyaframın yan kenarında oluşan yan vida birleşimi destek kuvvetleri $\left(F_{d-y k}\right)$ ise sırasıyla $(1),(\mathrm{m})$, (n) ve $(\mathrm{o})$ kolonlarında verilmiştir. Tablo 1'de görüldüğü gibi kayma diyaframı ideal sıkılı̆ğın 2 katı sıkılığa sahip diyaframlarla desteklenmiş çift simetri eksenli kirişlerde oluşan normalize edilmiş dönme değerleri 4.74 ile 3.57 arasında değișmektedir. Diyafram sıkılığı ideal sıkılığın 3 katına çıkarıldığında normalize edilmiş dönme değerleri ortalama \%28.5 düşmektedir. Diyafram sıkıllı̆ 1 ideal sıkılı̆̆ın 4 katına çıkarıldığında, normalize edilmiş dönme değerleri $3 Q_{i}$ sıkılı̆̆ındaki normalize edilmiş dönme değerlerine göre ortalama \%13; 5 katına çıkarıldığında, normalize edilmiş dönme değerleri $4 Q_{i}$ değerlerine göre ortalama $\% 7$ düşmektedir. Örneğin $L / d$ oranı 15 olan ÇS-160 \#1 kirişi için normalize edilmiş dönme değerleri, ideal diyafram sıkılığının $2,3,4$ ve 5 katı sıkılığa sahip diyaframlar için sırasıyla $4.22,2.98,2.59$ ve 2.40 'dır. $\mathrm{Bu}$ değerler normalize edilmiş dönme değerlerinde $\% 29, \% 13$ ve \%7'lik azalmalara karşılık gelmektedir.

Daha önce belirtildiği gibi, bir destek elemanı sadece deformasyonları kontrol etmek için değil, aynı zamanda destek kuvvetlerini kontrol etmek için de yeterli sıkılığa sahip 
Narin Çelik Kirişlere Stabilite Desteği Sağlayan Kayma Diyaframlarının...

olmalıdır. Bir diyafram plakasında oluşan destek kuvvetleri Şekil 1'de gösterilmişti. Şekil 1'de görüldüğ̈̈ gibi bir diyafram plakasında iki çeşit destek kuvveti oluşur: 1) kayma diyaframlarını kiriş üst başlığına bağlayan kısa kenar vida birleşimlerinde oluşan destek kuvvetleri $\left(F_{d-k k}\right)$; 2) kayma diyaframlarını birbirlerine bağlayan yan vida birleşimlerinde oluşan destek kuvvetleri $\left(F_{d-y k}\right)$. Şekil 1'de görüldüğü gibi diyafram plakasının kısa kenarında hem dikey, hem de yatay yönde destek kuvveti bileşenleri oluşmakta iken, yan kenarında sadece dikey yönde destek kuvveti oluşmaktadır. Diyafram plakasının kısa ve yan kenarında oluşan destek kuvvetlerinin kiriş uzunluğunca dağılımı $L / d$ oranı 10 olan ÇS100 \#1 kirişi için Şekil 8'de gösterilmektedir. Diyafram sıkılığı, ideal sıkılı̆ğın 4 katı olarak alınmıştır. Dikey eksende destek kuvveti, yatay eksende ise kiriş uzunluğunun yarısı gösterilmektedir. Yatay eksende kiriş uzunluğunun yarısının gösterilmesinin sebebi, destek kuvvetlerinin kiriş orta açıklığına göre simetrik olmasıdır. Kesik çizgili eğriler kısa kenar vida birleşimi destek kuvvetlerini, düz çizgili tek eğri ise yan vida birleşimi destek kuvvetlerini göstermektedir. $L / d$ oran 10 olan ÇS-100 \#1 kirişinde toplam 24 diyafram plakası mevcuttur. Şekil 8'de kirişin sadece yarısı gösterildiği için toplam 12 kesik çizgili eğri vardır. Şekil 8'de görülen her bir kesik çizgili eğri, bir diyafram plakasına aittir. Eğrilerin üzerindeki “×” işaretleri her bir vida birleşiminde oluşan destek kuvvetini göstermektedir. Daha önce açıklandığı gibi, sonlu elemanlar modelinde kısa kenar vida birleşimleri birbirine dik iki yönde rijitliğe sahip boyutsuz yay elemanlar kullanılarak modellenmişti. Bu modelleme neticesinde, sonlu elemanlar analizlerinden Şekil 1'de kısa kenar birleşimleri için gösterilen dikey ve yatay vida birleşimi destek kuvveti bileşenlerinin değerleri elde edilmiştir. Şekil 8'de gösterilen her bir kısa kenar vida birleşimi destek kuvveti $\left(F_{d-k k}\right)$, birleşimde oluşan dikey ve yatay destek kuvveti bileşenlerinin karelerinin toplamının karekökü hesaplanarak elde edilmiştir. Görüldüğü gibi, bir diyafram plakasındaki kısa kenar vida birleşimi destek kuvvetlerinin en büyüğü ilk ve son vida birleşiminde oluşmaktadır. Kiriş uzunluğunda ise, en büyük destek kuvveti kiriş uzunluğunun dörtte biri civarında oluşmakta ve kiriş ortasına doğru destek kuvvetleri azalmaktadır.

Şekil 8'de gösterilen düz çizgili yan vida birleşimi destek kuvvetleri eğrisindeki “ $\times$ " işaretleri, diyafram plakalarının birleştikleri her bir kenardaki bir adet yan kenar birleşim vidasında oluşan ortalama destek kuvvetini ifade etmektedir. Her bir kenardaki ortalama destek kuvveti, sonlu elemanlar modelinde yan kenar vida birleşimlerini temsil eden makas elemanında oluşan kuvvetin, toplam vida sayısına (5) bölünmesiyle elde edilmiştir. Daha önce belirtildiği üzere, her bir kenarda diyafram plakalarının 5 adet vida ile birbirlerine bağlandıkları kabul edilmiştir. Yan vida birleşimi destek kuvvetlerinin kiriş uzunluğu boyunca dağıllımı, kısa kenar vida birleşimi destek kuvvetlerinin kiriş uzunluğunca dağılımına benzer şekilde, yan vida birleşimi destek kuvvetleri de kiriş uzunluğunun dörtte biri civarında en büyük değerine ulaşmakta ve kiriş orta açıklı̆̆ına doğru azalarak dikkate alınmayacak değerlere inmektedir. Bu tür bir davranışın başlıca sebebi, kiriş üst başlığında oluşan kayma deformasyonlarının mesnetten çeyrek kiriş uzunluğu mesafede maksimuma ulaşmasıdır. Kiriş orta açıklığı bölgesinde ise kayma deformasyonları oluşmamakta; üst başlık sadece yatay olarak hareket etmektedir. 


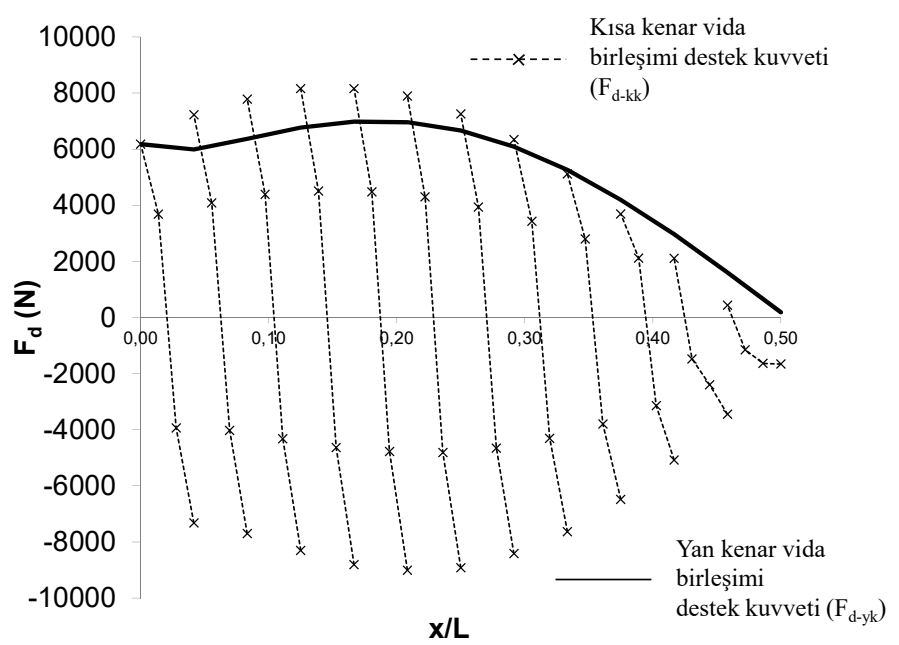

Şekil 8. L/d oranı 10 olan ÇS-100 \#1 kirişi için diyafram plakası kısa ve yan kenar destek kuvvetleri dağıllmı $\left(Q=4 Q_{i}\right)$

Tüm çift simetri eksenli kesitlerin kısa kenar ve yan kenar destek kuvvetlerinin tasarım momenti seviyesindeki değerleri Tablo 1'de verilmiştir. Tablo 1'in (h), (i), (j) ve (k) kolonlarında ideal diyafram sıkılığının sırasıyla iki, üç, dört ve beş katı sıkılığa sahip diyaframlarla desteklenmiş kirişler için kısa kenar destek kuvvetleri, (l), (m), (n) ve (o) kolonlarında ise sırasıyla yan kenar birleşimi destek kuvvetleri değerleri verilmiş̧ir. Tablo 1'de görüldüğü gibi kısa ve yan kenar birleşimi destek kuvvetleri diyaframın sıkılığ arttıkça azalmaktadır. Diyafram sıkılığı ideal sıkılığın 3 katına çıkarıldığında, kısa ve yan kenar vida birleşimi destek kuvvetleri, ideal sıkılığın iki katı sıkılığa sahip diyaframlarla desteklenen kirişlerde oluşan kısa kenar vida birleşimi destek kuvvetlerine göre ortalama \%25.5 azalmaktadır. Diyafram sıkılığı ideal sıkılığın 4 katına çıkarıldığında, kısa ve yan kenar vida birleşimi destek kuvvetleri, $3 Q_{i}$ sıkılığındaki destek kuvvetlerine göre ortalama $\% 10.5,5$ katına çıkarıldığında, destek kuvvetleri $4 Q_{i}$ değerlerine göre ortalama $\% 5.5$ düşmektedir. Örneğin $L / d$ oran 15 olan ÇS-160 \#1 kirişi için kısa kenar vida birleşimi destek kuvveti değerleri, ideal diyafram sıkılığının $2,3,4$ ve 5 katı sıkılığa sahip diyaframlar için sırasıyla 14608, 10738, 9614 ve 8990 N'dur. Bu değerler \%26.5, \%10.5 ve \%6.5'lik azalmalara karşılık gelmektedir.

Gövde narinlik oranı, kiriş derinliği ve $L / d$ oranının orta açıklık dönmesine ve destek kuvvetlerine etkileri de Tablo 1'de gözlenebilmektedir. Gövde narinlik oranının etkilerini gözlemlemek için $L / d$ oranı 15 ve diyafram sıkıllığ $3 Q_{i}$ olan ÇS-100 \#1 $\left(d=1464, h / t_{w}=\right.$ $100)$ ve ÇS-160 \#1 $\left(d=1464, h / t_{w}=160\right)$ kirişlerinin normalize edilmiş orta açıklık dönme değerleri ile kısa ve yan kenar vida birleşimi destek kuvvetleri karşılaştırılacaktır. Belirtilen $L / d$ oranı ve diyafram sıkılığına sahip ÇS-100 \#1 kirişinin normalize edilmiş orta açıklık dönme değerleri ile kısa ve yan kenar vida birleşimi destek kuvvetleri sırasıyla 2.87, 11861 N, ve 9212 N'dur. Gövde narinlik oranı 160 olan ÇS-160 \#1 kirişinin aynı diyafram 
Narin Çelik Kirişlere Stabilite Desteği Sağlayan Kayma Diyaframlarının...

sıkılı̆̆ındaki normalize edilmiş orta açıklık değeri \%3.8 artarak 2.98 olmakta, kısa kenar vida birleşimi destek kuvveti \%9.5 azalarak $10738 \mathrm{~N}$ ve yan kenar vida birleşimi destek kuvveti \%8.8 azalarak $8407 \mathrm{~N}$ olmaktadır. Diğer kiriş kesitleri ve diyafram sıkılıklarında de benzer davranış gözlenmektedir. Gövde narinlik oranı artırıldığında kiriş alt başlığı daha fazla yanal deplasman yapmakta ve kirişin dönme miktarı artmaktadır. Gövde narinlik oranı arınca vida birleşim destek kuvvetlerinin azalmasının sebebi ise, narinlik oranı yüksek olan kirişin burkulmasını sağlamak için, düşük narinlik oranına sahip kirişlerin burkulma yükünden daha düşük yüklere ihtiyaç duyulmasıdır.

Tablo 1. Çift simetri eksenli kirişlerin normalize edilmiş dönme değerleri ve destek kuvvetleri

\begin{tabular}{|c|c|c|c|c|c|c|c|c|c|c|c|c|c|c|}
\hline (a) & (b) & (c) & (d) & (e) & (f) & (g) & (h) & (i) & (j) & $(\mathrm{k})$ & (I) & (m) & (n) & (o) \\
\hline \multirow{2}{*}{ Kesit } & \multirow{2}{*}{$\begin{array}{c}\text { Kesit } \\
\text { Özellikleri }\end{array}$} & \multirow{2}{*}{$L / d$} & \multicolumn{4}{|c|}{$\theta_{T} / \theta_{o}$} & \multicolumn{4}{|c|}{$F_{d-k k}(\mathrm{~N})$} & \multicolumn{4}{|c|}{$F_{d-y k}(\mathrm{~N})$} \\
\hline & & & $2 Q_{\text {ideal }}$ & $3 Q_{\text {ideal }}$ & $4 Q_{\text {ideal }}$ & $5 Q_{\text {ideal }}$ & $2 Q_{\text {ideal }}$ & $3 Q_{\text {ideal }}$ & $4 Q_{\text {ideal }}$ & $5 Q_{\text {ideal }}$ & $2 Q_{\text {ideal }}$ & $3 Q_{\text {ideal }}$ & $4 Q_{\text {ideal }}$ & $5 Q_{\text {ideal }}$ \\
\hline \multirow{2}{*}{ ÇS- $100 \# 1$} & $b_{f}=300 \mathrm{~mm}$ & 10 & 3,57 & 2,57 & 2,24 & 2,08 & 13110 & 9989 & 8990 & 8549 & 10225 & 7758 & 6981 & 6618 \\
\hline & $d=1464 \mathrm{~mm}$ & 15 & 3,99 & 2,87 & 2,50 & 2,33 & 15857 & 11861 & 10613 & 9989 & 12354 & 9212 & 8238 & 7779 \\
\hline \multirow{2}{*}{ ÇS- $160 \# 1$} & $b_{f}=300 \mathrm{~mm}$ & 10 & 3,83 & 2,72 & 2,36 & 2,18 & 12486 & 9364 & 8365 & 7991 & 9759 & 7319 & 6549 & 6191 \\
\hline & $d=1464 \mathrm{~mm}$ & 15 & 4,22 & 2,98 & 2,59 & 2,40 & 14608 & 10738 & 9614 & 8990 & 11476 & 8407 & 7475 & 7042 \\
\hline \multirow{2}{*}{ ÇS- $100 \# 2$} & $b_{f}=300 \mathrm{~mm}$ & 10 & 3,74 & 2,73 & 2,39 & 2,22 & 17405 & 13222 & 11899 & 11275 & 13591 & 10306 & 9266 & 8772 \\
\hline & $d=1830 \mathrm{~mm}$ & 15 & 4,38 & 3,13 & 2,74 & 2,55 & 21725 & 15982 & 14234 & 13344 & 17011 & 12483 & 11090 & 10424 \\
\hline \multirow{2}{*}{ ÇS- $160 \# 2$} & $b_{f}=300 \mathrm{~mm}$ & 10 & 3,96 & 2,88 & 2,52 & 2,34 & 15520 & 11724 & 10525 & 9976 & 12124 & 9151 & 8205 & 7772 \\
\hline & $d=1830 \mathrm{~mm}$ & 15 & 4,74 & 3,30 & 2,87 & 2,66 & 19603 & 13984 & 12361 & 11612 & 15348 & 10969 & 9705 & 9117 \\
\hline
\end{tabular}

Gövde narinlik oranı ile $L / d$ sabit tutulduğunda, derinliği fazla olan kirişlerde oluşan dönme miktarı ve vida birleşimi destek kuvvetleri daha büyüktür. Örneğin $h / t_{w}=100, L / d=15$ ve $Q=3 Q_{i}$ olan kirişin normalize edilmiş orta açıklık dönme değeri ile kısa ve yan kenar vida birleşimi destek kuvvetleri sırasıyla 2.87, $11861 \mathrm{~N}$, ve 9212 N'dur. Diyafram sıkılığı ve $L / d$ oranı sabit tutulup kiriş derinliği artırıldığında (ÇS-100 \#2, $d=1830 \mathrm{~mm}$ ) normalize edilmiş orta açıklık değeri \%9.1 artarak 3.13 olmakta, kısa kenar vida birleşimi destek kuvveti \%34.7 artarak $15982 \mathrm{~N}$ ve yan kenar vida birleşimi destek kuvveti \%35.5 artarak $12483 \mathrm{~N}$ olmaktadır. Kiriş derinliği artırılınca vida birleşim destek kuvvetlerinin artmasının sebebi, derinliği fazla olan kirişin burkulmasını sağlamak için, düşük derinliğe sahip kirişlerin burkulma yükünden daha yüksek yüklere ihtiyaç duyulmasıdır. Gövde narinlik oranı ile derinlik sabit tutulduğunda ise, yüksek $L / d$ 'ye sahip kirişte dönme miktarının ve vida birleşimi destek kuvvetlerinin daha büyük olduğu gözlenmektedir. Örneğin $h / t_{w}=100$, $L / d=10, d=1464 \mathrm{~mm}$ ve $Q=3 Q_{i}$ olan kirişin (ÇS-100 \#1, $L / \mathrm{d}=10$ ) normalize edilmiş orta açıklı dönme değeri ile kısa ve yan kenar vida birleşimi destek kuvvetleri sırasıyla 2.57, 
9989 N, ve 7758 N'dur. Kiriş uzunluğunun derinliği oranı 15 olan ÇS-100 \#1 kirişinde ise normalize edilmiş orta açıklık değeri \%11.7 artarak 2.87 olmakta, kısa kenar vida birleşimi destek kuvveti \%18.7 artarak $11861 \mathrm{~N}$ ve yan kenar vida birleşimi destek kuvveti \%18.7 artarak 9212 N olmaktadır. Diğer kiriş kesitleri ve diyafram sıkılıklarında de benzer davranış gözlenmektedir.

\subsection{Tek Simetri Eksenli Kirişler}

Tek simetri eksenli kirişlerin tümü için elde edilmiş sonlu elemanlar çözümleme sonuçları Tablo 2'de verilmiştir. Daha önce belirtildiği gibi, tek simetri eksenli kirişlerde sadece derinliği $1464 \mathrm{~mm}$ olan kesitler irdelenmiştir. Tablo 2'nin formatı, Tablo 1'in formatının aynısıdır. İlk üç kolon ((a), (b) ve (c)) kesitin ismini, özelliklerini ve $L / d$ oranlarını içermektedir. Sonraki dört kolon ((d), (e), (f) ve (g)) kayma diyaframı ideal sıkılığının 2, 3, 4 ve 5 katı sıkılığa sahip diyaframlarla desteklenmiş kirişlerde oluşan normalize edilmiş dönme değerlerini içermektedir. Sonraki dört kolon ((h), (i), (j) ve (k)) aynı diyafram sıkılıklarında, diyaframın kısa kenar vida birleşimlerinde oluşan destek kuvvetlerini içermektedir. Son dört kolon da ((1), (m), (n) ve (o)) aynı diyafram sıkılıklarında diyaframın yan kenarında oluşan yan vida birleşimi destek kuvvetlerini içermektedir. Tablo 2'de görüldüğü gibi kayma diyaframı ideal sıkılığının 2 katı sıkılığa sahip diyaframlarla desteklenmiş tek simetri eksenli kirişlerde oluşan normalize edilmiş dönme değerleri 4.16 ile 3.24 arasında değişmektedir. Diyafram sıkılığı ideal sıkılığın 3 katına çıkarıldığında normalize edilmiş dönme değerleri ortalama \%29.1 düşmektedir. Diyafram sıkılı̆̆ ideal sıkılığın 4 katına çıkarıldığında, normalize edilmiş dönme değerleri $3 Q_{i}$ sıkılığındaki normalize edilmiş dönme değerlerine göre ortalama $\% 13.0 ; 5$ katına çıkarıldığında, normalize edilmiş dönme değerleri $4 Q_{i}$ değerlerine göre ortalama $\% 7.3$ düşmektedir. Örneğin $h / t_{w}=100, L / d=10$, ve $I_{y c} I_{y}=0.29$ olan TS-100 \#29 kirişinin normalize edilmiş dönme değerleri, ideal diyafram sıkılığının 2, 3, 4 ve 5 katı diyafram sıkılığ i için sırasıyla $3.33,2.41,2.10$, ve $1.95^{\prime}$ dir. Bu değerler normalize edilmiş dönme değerlerinde $\% 27.6$, $\% 12.6$ ve \%7.2'lik azalmalara karşılık gelmektedir.

Normalize edilmiş orta açıklık dönmelerindeki azalmaya benzer olarak, diyaframın sıkılığı artırıldıkça vida birleşim destek kuvvetleri de azalmaktadır. Diyafram sıkılığı ideal sıkılığın 3 katına çıkarıldığında kısa ve yan kenar vida birleşimi destek kuvvetleri ortalama \%26.6 düşmektedir. Diyafram sıkılığı ideal sıkılığın 4 katına çıkarıldığında, kısa ve yan kenar vida birleşimi destek kuvvetleri $3 Q_{i}$ sıkılığındaki kısa ve yan kenar vida birleşimi destek kuvvetlerine göre ortalama \%11.1; 5 katına çıkarıldığında, kısa ve yan kenar vida birleşimi destek kuvvetleri $4 Q_{i}$ değerlerine göre ortalama \%5.8 düşmektedir. Örneğin $h / t_{w}=100, L / d$ $=10$, ve $I_{y c} / I_{y}=0.29$ olan TS-100 \#29 kirişinin kısa kenar vida birleşimi destek kuvvetleri, ideal diyafram sıkılığının 2, 3, 4 ve 5 katı diyafram sıkılığ 1 için sırasıyla 10675, 8066, 7229 ve 6842 N'dur. Bu değerler kısa kenar vida birleşimi destek kuvvetlerinde \%24.4, \%10.4 ve \%5.4'lük azalmalara karşılık gelmektedir. Benzer azalma oranları yan vida birleşimi destek kuvvetlerinde de gözlenmektedir.

Tek simetri eksenli kirişlerde de, çift simetri eksenli kirişlere benzer olarak gövde narinlik oranı ve kiriş derinliği sabit tutulup $L / d$ oranı artırılınca normalize edilmiş orta açıklık dönme miktarı ile destek kuvvetleri artmakta; $L / d$ oranı ve kiriş derinliği sabit tutulup gövde narinlik oranı artırıldığında normalize edilmiş orta açıklık dönme miktarı artmakta, 
Narin Çelik Kirişlere Stabilite Desteği Sağlayan Kayma Diyaframlarının...

destek kuvvetleri azalmaktadır. Mono-simetri oranın normalize edilmiş orta açıklık dönme değerlerine ve destek kuvvetlerine etkileri de Tablo 2'de incelenebilmektedir. TS-100 \#19, \#29 ve \#39 kirişlerinin $L / d=10$ ve $Q=3 Q_{i}$ için normalize edilmiş orta açıklık dönme değerleri sırasıyla $2.34,2.41$ ve 2.50 'dir; kısa kenar vida birleşimi destek kuvvetleri sırasiyla 7254, 8066 ve 9027 N'dur; yan kenar vida birleşimi destek kuvvetleri sırasıyla 5657,6265 ve $7002 \mathrm{~N}$ 'dur. Görüldüğü gibi normalize edilmiş orta açılılk dönme değerleri ile kısa ve yan kenar vida birleşimi destek kuvvetleri mono-simetri oranı arttıkça artmaktadır. Bunun sebebi, mono-simetri oranı arttıkça kirişlerin tasarım yüklerinin artmasidır.

Tablo 2. Çift simetri eksenli kirişlerin normalize edilmiş dönme değerleri ve destek kuvvetleri

\begin{tabular}{|c|c|c|c|c|c|c|c|c|c|c|c|c|c|c|}
\hline (a) & (b) & (c) & (d) & (e) & (f) & (g) & (h) & (i) & (j) & (k) & (I) & (m) & (n) & (o) \\
\hline \multirow{2}{*}{ Kesit } & \multirow{2}{*}{$\begin{array}{c}\text { Kesit } \\
\text { Özellikleri }\end{array}$} & \multirow{2}{*}{$L / d$} & \multicolumn{4}{|c|}{$\theta_{T} / \theta_{o}$} & \multicolumn{4}{|c|}{$F_{d-k k}(\mathrm{~N})$} & \multicolumn{4}{|c|}{$F_{d-y k}(\mathrm{~N})$} \\
\hline & & & $2 Q_{\text {ideal }}$ & $3 Q_{\text {ideal }}$ & $4 Q_{\text {ideal }}$ & $5 Q_{\text {ideal }}$ & $2 Q_{\text {ideal }}$ & $3 Q_{\text {ideal }}$ & $4 Q_{\text {ideal }}$ & $5 Q_{\text {ideal }}$ & $2 Q_{\text {ideal }}$ & $3 Q_{\text {ideal }}$ & $4 Q_{\text {ideal }}$ & $5 Q_{\text {ideal }}$ \\
\hline \multirow{3}{*}{ TS- $100 \# 19$} & $b_{c f}=210 \mathrm{~mm}$ & \multirow{2}{*}{10} & \multirow{2}{*}{3,24} & \multirow{2}{*}{2,34} & \multirow{2}{*}{2,05} & \multirow{2}{*}{1,90} & \multirow{2}{*}{9701} & \multirow{2}{*}{7254} & \multirow{2}{*}{6493} & \multirow{2}{*}{6143} & \multirow{2}{*}{7576} & \multirow{2}{*}{5657} & \multirow{2}{*}{5055} & \multirow{2}{*}{4771} \\
\hline & $I_{y c} / I_{y}=0.19$ & & & & & & & & & & & & & \\
\hline & $\begin{array}{l}d=1464 \mathrm{~mm} \\
h / t_{w}=100\end{array}$ & 15 & 3,73 & 2,66 & 2,32 & 2,16 & 11512 & 8390 & 7441 & 6992 & 8982 & 6535 & 5792 & 5447 \\
\hline & $b_{c f}=240 \mathrm{~mm}$ & 10 & 3,33 & 2,41 & 2,10 & 1,95 & 10675 & 8066 & 7229 & 6842 & 8319 & 6265 & 5616 & 5312 \\
\hline TS- $100 \# 29$ & $I_{y c} / I_{y}=0.29$ & & & & & & & & & & & & & \\
\hline $15-100+125$ & $\begin{array}{l}d=1464 \mathrm{~mm} \\
h / t_{w^{\prime}}=100\end{array}$ & 15 & 3,84 & 2,73 & 2,38 & 2,21 & 12848 & 9427 & 8365 & 7878 & 10016 & 7346 & 6522 & 6137 \\
\hline & $b_{c f}=270 \mathrm{~mm}$ & 10 & 3,49 & 2,50 & 2,18 & 2,02 & 11974 & 9027 & 8103 & 7666 & 9320 & 7002 & 6278 & 5941 \\
\hline TS-100 $\# 30$ & $I_{y c} / I_{y}=0.39$ & & & & & & & & & & & & & \\
\hline & $d=1464 \mathrm{~mm}$ & 15 & 396 & 281 & 245 & 228 & 14409 & 10600 & 9427 & 8877 & 11246 & 8259 & 7353 & 6920 \\
\hline & $h / t_{w}=100$ & 15 & 5,90 & 2,01 & $2,4 J$ & 2,20 & 14409 & 10000 & 9421 & 0011 & 11240 & 0259 & ה & 0920 \\
\hline & $b_{c f}=210 \mathrm{~mm}$ & 10 & 353 & 246 & 213 & 107 & 8852 & 6430 & 5603 & 5356 & 6014 & 5021 & 454 & 4100 \\
\hline TS-160 $\# 10$ & $I_{y c} / I_{y}=0.19$ & & ( & 2,40 & 2,13 & 1,91 & 0052 & 0450 & 5095 & 5330 & 6914 & 5021 & 4454 & 4190 \\
\hline & $d=1464 \mathrm{~mm}$ & 15 & 402 & 77 & 230 & (2) & 10276 & 7070 & 6303 & 5081 & 8076 & 5607 & 5001 & 4683 \\
\hline & $h / t_{w}=160$ & 15 & 4,02 & $2, / 1$ & 2,39 & 2,21 & 10376 & 7279 & 6393 & 5981 & 8076 & 5697 & 5001 & 4683 \\
\hline & $b_{c f}=240 \mathrm{~mm}$ & 10 & 357 & $25 ?$ & 210 & 203 & 0801 & 7200 & 6443 & 6068 & 7657 & 5636 & 5015 & 4731 \\
\hline TS-160\# 20 & $I_{y c} / I_{y}=0.29$ & 10 & ( & 2,32 & 2,19 & 2,03 & 9801 & 1229 & 6443 & 6008 & $705 \%$ & 5636 & 5015 & $4 / 31$ \\
\hline $10-10045$ & $d=1464 \mathrm{~mm}$ & 15 & 1 01 & 281 & 24 & 226 & 11325 & 0170 & 2 & 6700 & (80) & 5 & ? & 210 \\
\hline & $h / t_{w}=160$ & 15 & 4,01 & 2,81 & 2,44 & 2,26 & 11325 & 8178 & 7242 & 6792 & 8880 & 6407 & 5663 & 5319 \\
\hline & $b_{c f}=270 \mathrm{~mm}$ & 10 & 366 & 261 & 226 & 210 & 10925 & 8178 & 7317 & 6917 & 8563 & 6380 & 5704 & 5386 \\
\hline TS-160\# 30 & $I_{y c} / I_{y}=0.39$ & 10 & 5,00 & 2,01 & 2,20 & 2,10 & 10923 & 0170 & - & 0917 & 0505 & 0500 & 3104 & 5300 \\
\hline | & $d=1464 \mathrm{~mm}$ & 15 & 416 & 291 & 252 & 234 & 12095 & 0402 & 8328 & 7820 & 10171 & 7353 & 6515 & 6116 \\
\hline & $h / t_{w}=160$ & 15 & 4,10 & 2,91 & 2,52 & 2,04 & & & & & & & & \\
\hline
\end{tabular}

\subsection{Kiriş Uzunluğunca Çapraz Destek Elemanları ile Desteklenmiş Kirişler}

Daha önce bahsedildiği gibi çelik I-kirişlerin tasarımında yanal burulmalı burkulma sınır durumu, özellikle uzun kirişlerde belirleyici olabilmektedir. Bu gibi kirişlerin montaj sırasındaki burkulma momentini artırmak için genellikle noktasal destek elemanları kullanılmaktadır. Kayma diyaframı ile desteklenen bu tür kirişlerin davranışının 
incelenebilmesi için $L / d$ oranları 20 ve 30 olan ve kiriş açıklığının ortasında çapraz destek elemanı bulunduran kirişler analiz edilmiştir. Çapraz noktasal destek elemanları bir kirişin üst başlığını diğer kirişin alt başlığına bağlayan ve rijitliği çok yüksek olan makas elemanlarla modellenmiştir. Analizler tüm kesitler için yapılmış olsa da burada sadece $L / d$ oranları 20 ve 30 olan ÇS-100 \#1 kesitinin analiz sonuçları irdelenecektir. Diğer kiriş analizlerinde de benzer sonuçlar elde edilmiştir.

Şekil 9'da $L / d$ oranları $10,15,20$ ve 30 olan ÇS-100 \#1 kesitleri için kiriş uzunluğunca tasarım momenti seviyesinde oluşan orta açıklık dönme değerleri gösterilmektedir. Dikey eksen toplam dönme miktarın $\left(\theta_{t o p}\right)$, yatay eksen ise normalize edilmiş kiriş uzunluğunu $(x / L)$ göstermektedir. $L / d$ oranı 10 ve 15 olan kirişler için diyafram sıkıllı̆ 1 ideal diyafram sıkılı̆̆ının dört katı $\left(Q=4 Q_{i}\right), L / d$ oran 20 ve 30 olan kirişler için diyafram sıkılığı ideal diyafram sıkılı̆̆ının iki katı $\left(Q=2 Q_{i}\right)$ olarak alınmıştır. Bunun sebebi, aşağıda da açıklandığı gibi, çapraz destek elemanı ile kiriş ortasında desteklenmiş kirişlerde oluşan dönme miktarının, desteksiz kirişlere nazaran çok düşük olmasıdır. Dönme miktarları kiriş ortasına göre simetrik olduğu için şekil sadece kirişlerin yarısına kadar olan $(x / L=0.5)$ dönme miktarlarını gösterilmektedir. Her ne kadar $L / d$ oranları 10, 15, 20 ve 30 olan kirişlerin boyları farklı olsa da, kiriş uzunlukları normalize edildiği için iki kiriş için de aynı şeklin kullanılması mümkün olmaktadır.

Şekil 9'da görüldüğü gibi, $L / d$ oranı 10 ve 15 olup diyafram sıkılı̆ğ ideal sıkılığın dört katı olan kirişlerde oluşan toplam dönme miktarları sırasıyla yaklaşık 0.045 ve 0.075 radyandır. Bu değerlerin orta açıklık ön kusur dönme değerlerine $\left(\theta_{0}=\left[\left(L_{b} / 500\right) / d\right]\right)$ bölünmesiyle elde edilen normalize edilmiş toplam dönme değerleri ise sırasıyla 2.24 ve 2.50 'dir. Bu değerler Tablo 1'de de verilmiştir. L/d oranı 20 olup orta açıklığında çapraz destek elemanı bulunduran ÇS-100 \#1 kirişinin uzunluğunda oluşan en yüksek toplam dönme değeri yaklaşık 0.042 radyandır. $\mathrm{Bu}$ değer mesnetten uzunluğun yaklaşık \%35'i mesafesinde oluşmakta, kiriş orta açıklığına yaklaştıkça düşmekte ve kiriş orta açıklığında 0.04 radyan olmaktadır. Kiriş orta açıklı̆̆ında, çapraz destek elemanının dönmeyi engellemesi neticesinde, yüklemeler esnasında dönme oluşmamaktadır. Ancak Şekil 9, tasarım momenti seviyesindeki toplam dönme değerlerini gösterdiği için kiriş orta açıklı̆̆ında $(x / L=0.5)$ toplam dönme değeri sıfır değil, ön kusur dönme değeri olan 0.004 radyana eşittir $\left(\theta_{0}=\right.$ $\left.\left[\left(L_{b} / 500\right) / d\right]\right)$. Bu kirişte, kiriş uzunluğunca oluşan en yüksek toplam dönme miktarının, bu değerin oluştuğu mesafedeki ön kusur dönme değerine bölünmesiyle elde edilen normalize edilmiş en yüksek dönme değeri $1.15^{\prime}$ 'dir. $L / d$ değeri 10 olan ÇS-100 \#1 kirişinin uzunluğu 14640 mm'dir. Kiriş uzunluğunun iki katına çıkartılıp açıklık ortasına çapraz destek elemanı yerleştirildiği ÇS-100 \#1 kirişinin $(L / d=20, L=29280 \mathrm{~mm})$ desteklenmemiş boyu da $14640 \mathrm{~mm}$ olmaktadır. $L / d$ oranı 10 olan ÇS-100 \#1 kirişinin normalize edilmiş en yüksek dönme değeri 2.24 iken, daha düşük diyafram sıkılığına sahip $\left(Q=4 Q_{i}\right.$ yerine $Q=$ $\left.2 Q_{i}\right) L / d$ oran 20 olan ÇS-100 \#1 kirişinin normalize edilmiş en yüksek dönme değeri 1.15 'e düşmüştür. $L / d$ oranları 15 ve 30 olan ÇS-100 \#1 kirişlerinin en yüksek toplam dönme değerleri sırası ile 0.075 ve 0.073 rad ve normalize edilmiş en yüksek dönme değerleri de sırasıyla 2.50 ve 1.39 'dur.

Şekil 10'da $L / d$ oranları $10,15,20$ ve 30 olan ÇS-100 \#1 kesitleri için kiriş uzunluğunca tasarım momenti seviyesinde oluşan kısa kenar destek kuvvetleri gösterilmektedir. Dikey eksen kısa kenar destek kuvvetini $\left(F_{d-k k}\right)$, yatay eksen ise normalize edilmiş kiriş uzunluğunu $(x / L)$ göstermektedir. Gösterilen destek kuvvetleri her bir diyafram plakasında 
Narin Çelik Kirişlere Stabilite Desteği Sağlayan Kayma Diyaframlarının...

oluşan en yüksek kısa kenar vida birleşim destek kuvvetini ifade etmektedir. Şekil 9'da olduğu gibi $L / d$ oranı 10 ve 15 olan kirişler için diyafram sıkılığı ideal diyafram sıkılığının dört katı $\left(Q=4 Q_{i}\right), L / d$ oranı 20 ve 30 olan kirişler için diyafram sıkılığı ideal diyafram sıkılığının iki katı $\left(Q=2 Q_{i}\right)$ olarak alınmıştır. Destek kuvvetleri kiriş ortasına göre simetrik olduğu için şekil sadece kirişlerin yarısına kadar olan $(x / L=0.5)$ destek kuvvetleri gösterilmektedir. Şekil 10'da görüldüğü gibi desteklenmemiş uzunlukları aynı olan çapraz destek elemanlı ve çapraz destek elemansız kirişlerin destek kuvvetleri arasında önemli bir fark oluşmaktadır. $L / d$ oran 10 ve 15 olan ÇS-100 \#1 kirişlerinde oluşan en yüksek kısa kenar destek kuvvetleri sırasıyla yaklaşık 9800 ve 8490 N'dir. Bu değerler, çapraz destek elemanına sahip $L / d$ oranları 20 ve 30 olan kirişlerde 1950 ve 1920 N'ye düşmektedir. Benzer davranış yan kenar destek kuvvetlerinde de gözlenmiştir. Daha önce belirtildiği gibi, diğer kiriş analizlerinde de benzer sonuçlar elde edilmiştir.

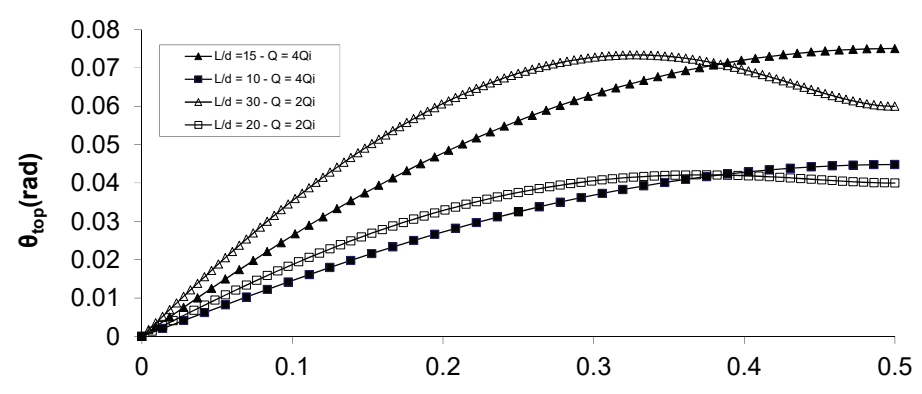

X/L

Şekil 9. L/d oranı 10, 15, 20 ve 30 olan ÇS-100 \#1 kirişleri için toplam dönme dă̆ı̆lımı

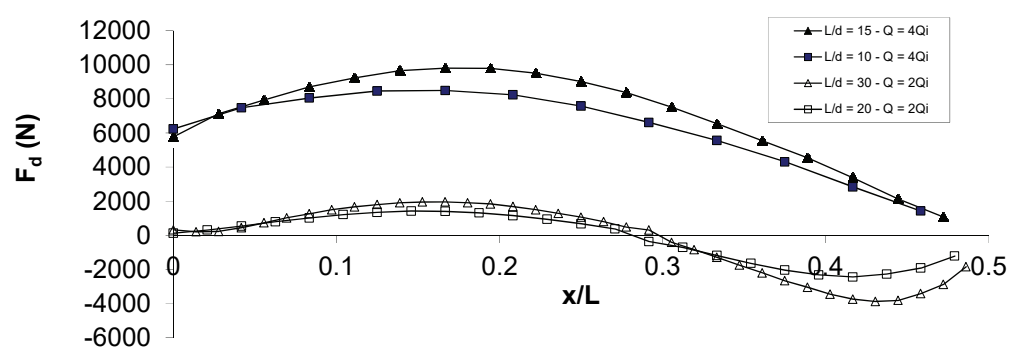

Şekil 10. L/d oranı 10, 15, 20 ve 30 olan ÇS-100 \#1 kirişleri için diyafram plakası kısa ve yan kenar destek kuvvetleri dağıllımı 


\section{DIYAFRAM RIJITTLIK GEREKLILIIĞí}

Bir önceki bölümde ortaya konan sonuçlar incelendiğinde ideal diyafram sıkılığının iki katı sıkılığa sahip diyaframlarla desteklenmiş çift ve tek simetri eksenli kirişlerde (kiriş uzunluğunca çapraz veya rijit birleşimli I- ve U-enkesitli destek elemanlarına sahip olmayan kirişler) normalize edilmiş orta açıklık dönme değerlerinin 3.3 ila 4.5 arasında değiştiği görülmektedir. Diyafram sıkılı̆̆ı ideal diyafram sıkılığının 3 katına çıkarıldığında (diyafram sıkılığının \%50 artırılması) normalize edilmiş orta açıklık dönme değerleri çift simetri eksenli kirişlerde \%28.5, tek simetri eksenli kirişlerde ortalama \%29.1 azalmıştır. Diyafram sıkılığı ideal diyafram sıkılığının 4 katına çıkarıldığında (diyafram sıkılığının \%33.3 artırılması) normalize edilmiş orta açıklık dönme değerleri çift simetri eksenli kirişlerde ortalama \%12.8, tek simetri eksenli kirişlerde ortalama \%13.0 azalmıştır. Diyafram sıkılığı ideal diyafram sıkılığının 5 katına çıkarıldığında (diyafram sıkılığının \%25 artırılması) normalize edilmiş orta açıklık dönme değerleri çift simetri eksenli kirişlerde ortalama \%7.2, tek simetri eksenli kirişlerde ortalama \%7.3 azalmıştır.

Aynı kirişler için kısa ve yan kenar vida birleşimleri destek kuvvetlerinde gözlenen azalma oranları da normalize edilmiş orta açıklık dönme değerleri azalma oranlarıyla benzerlik göstermektedir. Çift simetri eksenli kirişler için kısa kenar vida birleşimi destek kuvvetlerindeki azalmalar $2 Q_{i}{ }^{\prime}$ den $3 Q_{i}{ }^{\prime}$ ye çıkıldı̆̆ında ortalama $\% 28.7,3 Q_{i}$ 'den $4 Q_{i}{ }^{\prime}$ ye çıkıldığında ortalama $\% 11.2$ ve $4 Q_{i}$ 'den $5 Q_{i}^{\prime}$ 'ye çıkıldığında ortalama $\% 6.9$ olmuştur. Yan kenar vida birleşimi destek kuvvetlerindeki azalmalar $2 Q_{i}{ }^{\prime}$ den $3 Q_{i}$ 'ye çıkıldığında ortalama $\% 25.6,3 Q_{i}{ }^{\prime}$ den $4 Q_{i}{ }^{\prime}$ ye çıkıldığında ortalama $\% 10.7$ ve $4 Q_{i}$ 'den $5 Q_{i}$ 'ye çıkıldığında ortalama \%5.6 olmuştur. Tek simetri eksenli kirişler için kısa kenar vida birleşimi destek kuvvetlerindeki azalmalar $2 Q_{i}{ }^{\prime}$ den $3 Q_{i}{ }^{\prime}$ ye çıkıldığında ortalama $\% 27.4,3 Q_{i}$ 'den $4 Q_{i}{ }^{\prime}$ ye çıkıldığında ortalama \%11.6 ve $4 Q_{i}{ }^{\prime}$ den $5 Q_{i}{ }^{\prime}$ ye çıkıldığında ortalama $\% 6.0$ olmuştur. Yan kenar vida birleşimi destek kuvvetlerindeki azalmalar $2 Q_{i}$ 'den $3 Q_{i}$ 'ye çıkıldığında ortalama $\% 26.6,3 Q_{i}^{\prime}$ den $4 Q_{i}^{\prime}$ 'ye çıkıldığında ortalama $\% 11.1$ ve $4 Q_{i}$ 'den $5 Q_{i}$ 'ye çıkıldı̆̆ında ortalama $\% 5.8$ olmuştur.

Görüldüğ̈̈ gibi diyafram sıkılığının $4 Q_{i}$ 'den $5 Q_{i}$ 'ye çıkarıldığında oluşacak \%25'lik sıkılık artışı neticesinde normalize edilmiş orta açıklık dönme değerleri ile kısa ve yan kenar vida birleşimi destek kuvvetlerinde elde edilecek azalma oranı sadece $\% 7$ civarındadır. $\mathrm{Bu}$ azalma oranı, tasarımda kullanılacak güvenlik katsayıları ile kompanse edilebilecek bir oran olduğu için kiriş uzunluğu boyunca çapraz veya rijit birleşimli I- ve U-enkesitli destek elemanlarına sahip olmayan kirişler için gerekli diyafram sıkılığı, ideal diyafram sıkılığının dört katı olması uygun gözükmektedir. Bu durumda, $L / d$ oranı 15'e, $h / t_{w}$ oranı 160'a ve derinliği 1800 milimetreye kadar olan çift simetri eksenli kirişler ile $L / d$ oranı 15 'e, $h / t_{w}$ oranı 160'a ve derinliği 1450 milimetreye kadar olan tek simetri eksenli kirişlerin dış lifte $210 \mathrm{MPa}$ eğilme gerilmesine ulaşmalarını sağlayacak diyafram rijitliği aşağıda verilmiştir:

$\beta_{b r}^{\prime}=4 \beta_{i}^{\prime}=4 \frac{\left(M_{u}-C_{b}^{*} M_{g}\right)}{m d s_{d}}$

Bu denklemde $\beta_{b r}^{\prime}=$ deformasyon ve destek kuvvetlerinin kontrol edilebilmesi için gerekli olan diyafram rijitliği; $M_{u}=$ tasarım momenti; $\beta_{i}{ }_{i}=M_{u}$ 'ya ulaşmak için sağlanması gereken 
Narin Çelik Kirişlere Stabilite Desteği Sağlayan Kayma Diyaframlarının...

ideal diyafram rijitliği (Denklem (4) kullanılarak elde edilir); $C_{b}{ }^{*}=$ yük yüksekliğini de hesaba katan moment düzeltme katsayısı; $M_{g}=$ destek elemanı tarafından desteklenmemiş kirişin burkulma momenti; $m=$ yük konumu sabiti; $d=$ kiriş derinliği; ve $s_{d}=$ tek bir kirişi destekleyen diyafram genişliğidir. Denklemin nasıl kullanıldığını göstermek için Ek'de örnek bir problem çözülmüştür.

$L / d$ oranları 20 ve 30 olan ve orta açıklıklarında noktasal destek elemanları ile desteklenmiş kirişler incelendiğinde, diyafram sıkılığının ideal diyafram sıkılığının iki katı olduğu durumda dahi dönme ve vida birleşimi destek kuvvetlerinin çok düşük olduğu görülmüştür. $\mathrm{Bu}$ sebeple, bu tür kirişler için gerekli diyafram rijitliğinin $\left(\beta^{\prime}{ }_{b r}\right)$, ideal diyafram rijitliğinin $\left(\beta_{i}^{\prime}\right)$ iki katı olması uygun gözükmektedir.

Tasarımcılar, Denklem (7)'de belirtilen rijitliğe sahip bir diyaframı literatürde mevcut olan tabloları veya deney sonuçlarını kullanarak seçebilirler $[16,5,7]$. Denklem (7)'de şu tasarım katsayıları kullanılmalıdır kullanılmalıdır: (a) Yük ve dayanım katsayıları ile tasarımda as $\phi=0.65$; (b) Güvenlik katsayıları ile tasarımda $\phi=0.65(16,4]$.

\section{SONUÇ}

Kayma diyaframları ile desteklenmiş narin gövdeli kirişlerin yapım aşamasındaki burkulma davranışını incelemek ve diyaframların destek elemanı olarak kullanılmalarını sağlayacak rijitlik gerekliliğinin belirlenmesi amacıyla analitik bir çalışma yapılmıştır. Kayma diyaframları, kiriş üst başlıklarına ve birbirlerine basit vida birleşimleriyle bağlanırlar. Sonlu elemanlar modelinde her iki vida birleşimi de modellenmiştir. Çalışmada gövde narinlik oranı 100 ve 160 ve $L / d$ oran $10,15,20$ ve 30 olan çift ve tek simetri eksenli kesitlere sahip kirişler incelenmiştir. $L / d$ oranı 20 ve 30 olan kirişlerin orta açıklığına noktasal destek elemanları yerleştirilmiştir. Çift ve tek simetrili kirişlerde $L / d$ oranı arttığında dönme miktarlarının ve vida birleşim destek kuvvetlerinin arttığı, gövde narinlik oranı arttı̆̆ında ise dönme miktarlarının arttı̆̆ 1 ancak vida birleşim destek kuvvetlerinin azaldığı görülmüştür. Tek simetri eksenli kirişlerde mono-simetri oranı arttığında dönme miktarlarının ve vida birleşim destek kuvvetlerinin arttığı gözlenmiştir. Orta açıklığında çapraz destek elemanları ile desteklenmiş ve böylece desteklenmemiş kiriş uzunluğunun kiriş uzunluğunun yarısına indiği kirişlerde dönmeler ve destek kuvvetleri büyük oranda azalmıştır.

$\mathrm{Bu}$ çalışmada, kirişlerin yapım aşamasında tasarlanacağ tasarım momentinin kiriş dış lifinde $210 \mathrm{MPa}$ eğilme gerilmesi oluşturacak moment olduğu kabul edilmiştir. Kirişlerin yanal burulmalı burkulma kapasitelerini bu seviyeye çıkarmak için gerekli olan diyafram rijitliğinin, kiriş uzunluğu boyunca noktasal destek elemanlarıyla desteklenmemiş kirişler için ideal diyafram sıkılığının dört katı, desteklenmiş kirişler için ise iki katı olduğu gözlenmiştir.

\section{EK: TASARIM ÖRNEĞİ}

\section{Döșeme Sistemi:}

8 adet basit mesnetli yapma kirişten oluşmaktadır. Kirişler $12 \mathrm{~m}$ uzunluğundadır. Kirişler arası mesafe $2500 \mathrm{~mm}$ 'dir. Kesit özellikleri: $d=875 \mathrm{~mm}$ (derinlik), $t_{w}=8 \mathrm{~mm}$ (gövde 
kalınlı $\left.\breve{g}_{1}\right), h / t_{w}=105, b=150 \mathrm{~mm}$ (başlık genişliği), $t_{f}=10 \mathrm{~mm}$ (başlık kalınlı̆̆ı), $b / 2 t_{f}=$ 7.5 (başlı narinlik oranı), $J=22.9 \times 10^{4} \mathrm{~mm}^{4}$ (burulma sabiti), $C_{w}=10^{12} \mathrm{~mm}^{6}$ (çarpılma sabiti), $I_{y}=5.66 \times 10^{6} \mathrm{~mm}^{4}$.

Kiriş uzunluğunca noktasal destek elemanı bulunmamaktadır. Kirişler etki eden yapım aşaması tasarım momenti $446.3 \mathrm{kN}$-m'dir. Bu tasarım momenti kiriş dış lifinde $210 \mathrm{MPa}$ gerilme oluşturmaktadır.

\section{Yanal Burulmalı Burkulma Kapasitesi Kontrolü:}

Her ne kadar kirişin kendi ağırlı̆̆ı kiriş orta noktasına etki etse de, yükün büyük çoğunluğu (taze beton ve yapım aşaması servis yükleri) kiriş üst başlı̆ıına etki etmektedir. Bu durumda yükün tümünün üst başlığa etki ettiği varsayılabilir. Üst başlıktan yükleme sebebiyle, moment düzeltme katsayısı, $C_{b}$, yükün etki ettiği yüksekliğe bağlı olarak modifiye edilmelidir: $C_{b}{ }^{*}=C_{b} / 1.4$ [22]. Üst başlığa etki eden düzgün yayılı yük için $C_{b}=1.14$ olarak kabul edilebilir [22]. Bu durumda, $C_{b}{ }^{*}=C_{b} / 1.4=0.81$. Kirişin burkulma momenti şu denklemle hesap edilebilir [2]:

$$
\phi M_{n}=\phi C_{b}^{*} M_{g}=\phi C_{b}{ }^{*} \frac{\pi}{L_{b}} \sqrt{E I_{y} G J+\frac{\pi^{2} E^{2} C_{w} I_{y}}{L_{b}{ }^{2}}}=36.1 \mathrm{kN}-\mathrm{m}
$$

\section{Diyafram Destek Elemanı Rijitlik Gerekliliği:}

Kullanılacak diyaframın sahip olması gereken gerekli rijitlik, $G_{g}^{\prime}$, Denklem (5) ve (7) kullanılarak hesaplanabilir.

$$
\begin{aligned}
& s_{d}=\frac{(n-1) s_{g}}{n}=\frac{(8-1) 2.5}{8}=2.2 \mathrm{~m} \\
& \beta_{b r}^{\prime}=4 \beta_{i}^{\prime}=4 \frac{\left(M_{u}-\phi C_{b}^{*} M_{g}\right)}{s_{d} m d}=4 \frac{(446.3-36.1)}{2.2 \times 0.5 \times 0.875}=1705 \mathrm{kN} / \mathrm{m} / \mathrm{rad}
\end{aligned}
$$

Etkili diyafram rijitliği $1705 \mathrm{kN} / \mathrm{m} / \mathrm{rad}$ olan bir diyaframa ihtiyaç vardır.

\section{Semboller}

$C_{b}{ }^{*} \quad$ Yük yüksekliğini de hesaba katan moment düzeltme katsayısı

$C_{w} \quad$ Çarpılma sabiti $\left(\mathrm{mm}^{6}\right)$

E Çeliğin elastisite modülü $(M P a)$

$F_{d} \quad$ Diyaframın kenarlarında (kısa veya yan) oluşan vida birleşimi destek kuvveti $(N)$

$F_{d-k k} \quad$ Diyaframın kısa kenar vida birleşimlerinde oluşan destek kuvveti $(N)$

$F_{d-y k} \quad$ Diyaframın yan kenarındaki vida birleşimlerinde oluşan destek kuvveti $(N)$ 
Narin Çelik Kirişlere Stabilite Desteği Sağlayan Kayma Diyaframlarının...

$I_{y} \quad$ Kirişin zayıf ekseni etrafinda atalet momenti $\left(\mathrm{mm}^{4}\right)$

$I_{y c} \quad$ Basınç başlığının y-eksenine göre atalet momenti $\left(\mathrm{mm}^{4}\right)$

$J \quad$ Burulma sabiti $\left(\mathrm{mm}^{4}\right)$

$L \quad$ Kirişin uzunluğu $(m)$

$L_{b} \quad$ Kirişin desteklenmemiş uzunluğu $(m)$

$L_{k \varsigma} \quad$ Konsol çerçevenin uzunluğu $(\mathrm{mm})$

$M \quad$ Yüklemeler neticesinde kiriş orta açıklığında oluşan moment $(\mathrm{kN}-\mathrm{m})$

$M_{c r} \quad$ Kayma diyaframı ile desteklenmiş kirişin burkulma momenti $(k N-m)$

$M_{g} \quad$ Kirişin desteklenmemiş uzunluğundaki burkulma momenti $(k N-m)$

$M_{u} \quad$ Kiriş uzunluğundaki tasarım momenti $(k N-m)$

$P \quad$ Konsol çerçeveye etki eden kuvvet $(k N)$

$Q \quad$ Kayma diyaframının kayma sıkılığı $(k N / r a d)$

$Q_{i} \quad$ İdeal diyafram sikılı̆̆ $(k N / r a d)$

a Kiriş boyunca yerleştirilirmiş berkitme levhaları arasındaki mesafe $(\mathrm{mm})$

$b \quad$ Başlık genişliği $(\mathrm{mm})$

$b_{k c} \quad$ Konsol çerçevenin genişliği $(\mathrm{mm})$

$d \quad$ Kiriş derinliği $(\mathrm{mm})$

$e \quad$ kirişin ağırlık merkezi ile kayma diyaframının düzlemi arasındaki mesafe $(\mathrm{mm})$

$h \quad$ Hadde profillerinde, ağırlık merkezi ile basınç başlığının iç yüzündeki eğrilik bitim noktası arasındaki uzaklığın iki katı $(\mathrm{mm})$

$m \quad$ Yük konumu sabiti

n Toplam kiriş adeti

$s_{g} \quad$ Kirişler arası mesafe $(\mathrm{mm})$

$s_{d} \quad$ Bir kirişi destekleyen diyafram uzunluğu $(\mathrm{mm})$

$t_{w} \quad$ Gövde kalınlı̆̆ $(\mathrm{mm})$

$t_{f} \quad$ Başlık kalınlığ $(\mathrm{mm})$

w Konsol çerçeveyi destekleyen kayma diyaframının genişliği $(\mathrm{mm})$

$\beta \quad$ Kayma modülü $(k N / m / r a d)$

$\beta^{\prime} \quad$ Diyafram destek sisteminin etkili kayma rijitliği $(\mathrm{kN} / \mathrm{m} / \mathrm{rad})$

$\beta_{b r}^{\prime} \quad$ Deformasyon ve destek kuvvetlerinin kontrol edilebilmesi için gerekli olan diyafram rijitliği $(\mathrm{kN} / \mathrm{m} / \mathrm{rad})$

$\beta_{i}^{\prime} \quad M_{u}{ }^{\prime}$ ya ulaşmak için sağlanması gereken etkili ideal diyafram rijitliği $(\mathrm{kN} / \mathrm{m} / \mathrm{rad})$ 
$\Delta \quad$ Konsol çerçeve deplasmanı $(\mathrm{mm})$

$\gamma \quad$ Konsol çerçevede oluşan kayma gerinimi ( $\mathrm{rad} / \mathrm{rad})$

$\theta \quad$ Kiriş orta açıklığında yüklemeler sonucunda oluşan dönme ( $\mathrm{rad}$ )

$\theta_{0} \quad$ Kiriş orta açıklığındaki dönme geometrik ön kusuru ( $\left.\mathrm{rad}\right)$

$\theta_{T} \quad$ Kiriş orta açıklığında oluşan toplam dönme $(\mathrm{rad})$

$\tau^{\prime} \quad$ Etkili kayma gerilmesi $(\mathrm{kN} / \mathrm{m})$

\section{Kaynaklar}

[1] ANSYS, Finite Element Model Users Manual, (Version 11.0), ANSYS Inc., Canonsburg, Pa, USA, 2007.

[2] AISC, Specification for structural steel buildings, 14th Ed., Chicago, 2010.

[3] American Association of State Highway and Transportation Officials (AASHTO).Load and Resistance Factor Design (LRFD) Bridge Design Specifications, $7^{\text {th }}$ Ed., Washington, D.C., 2014.

[4] CANAM, Steel Deck Diaphragm Catalogue, Boucherville.Davies J.M., Bryan E.R. (1982). Manual of Stressed Skin Diaphragm Design, JW\&S, NY, USA, 2007.

[5] Davies J. M., and Bryan E. R., Manual of Stressed Skin Diaphragm Design, Wiley Press, 1982.

[6] Egilmez, O. O. And Alkan, D., "Çelik köprü I-kirişlerine yanal destek sağlayan trapez sac kalıpların mukavemeti," Teknik Dergi, 20, 4891-4904, 2009.

[7] Egilmez, O. O., Helwig, T., Jetann, C., Lowery, R., "Stiffness and strength of metal bridge deck forms", Journal of Bridge Engineering, 12(4), 429-437, 2007.

[8] Egilmez, O. O, Herman, R., Helwig, T., "Lateral stiffness of steel bridge I-girders braced by metal deck forms", Journal of Bridge Engineering, 14(1), 17-25, 2009.

[9] Egilmez, O. O., Helwig, T., Herman, R., "Buckling behavior of steel bridge I-girders braced by permanent metal deck forms", Journal of Bridge Eng., 17(4), 624-633, 2012.

[10] Egilmez, O., Helwig, T., and Herman, R., "Using metal deck forms for construction bracing of steel bridges," J. Bridge Engrg., ASCE, in press, 2016.

[11] Errera, S. and Apparao, T. (1976), "Design of I-shaped beams with diaphragm bracing", Journal of the Structural Division, 102(4), 769-781.

[12] Helwig, T. A. and Frank, K. H., "Stiffness requirements for diaphragm bracing of beams", Journal of Structural Engineering, 125(11), 1249-1256, 1999.

[13] Helwig, T. A. and Yura, J. A. (2008a), "Shear diaphragm bracing of beams. I: Stiffness requirements", Journal of Structural Engineering , 134(3), 348-356. 
Narin Çelik Kirişlere Stabilite Desteği Sağlayan Kayma Diyaframlarının...

[14] Helwig, T. A. and Yura, J. A. (2008b), "Shear diaphragm bracing of beams. II: Design requirements", Journal of Structural Engineering, 134(3), 357-363.

[15] Luttrell, L. D. \& Steel Deck Institute (1981). Steel Deck Institute diaphragm design manual, $1^{\text {st }}$ Ed., MO.

[16] Luttrell, L. D. \& Steel Deck Institute (2004). Steel Deck Institute diaphragm design manual, $3^{\text {rd }}$ Ed., Canton.

[17] Nethercot, D. and Trahair, N. (1975), "Design of diaphragm-braced I-beams", Journal of the Structural Division, 101(10), 2045-2061.

[18] Türkye Cumhuriyet, Çevre ve Şehircilik Bakanlığı, Çelik yapıların tasarım ve yapım kurallarl, Ankara, 2016

[19] Wang, L. and Helwig, Todd A. (2005), "Critical imperfections for beam bracing systems", Journal of Structural Engineering, 131(6), 933-940.

[20] Winter, G. (1960), "Lateral bracing of columns and beams", Trans. Am. Soc. Civ. Eng., 125(1), 807-826.

[21] Yura, J., A. (2001), "Fundamentals of beam bracing", Eng. J., 38(1), 11-26.

[22] Ziemian, R., ed. (2110), Guide to Stability Design Criteria for Metal Structures, $6^{\text {th }}$ Ed., JW \& S, USA. 